\title{
Erosion Surface and Granitic Morphology in the Sierra de Lihuel Calel, Province of La Pampa, Argentina
}

\author{
Emilia Y. Aguilera, Ana Maria Sato, Eduardo Llambías, and Hugo Tickyj
}

\begin{abstract}
This chapter aims to characterize the landforms of the ignimbrite landscape in the Sierra de Lihuel Calel, province of La Pampa, Argentina. DEM data from SRTM were used for the analysis of morphometric characteristics and other parameters, so as to obtain longitudinal profiles and identify the boundaries of the paleosurface. By means of the interpretation of satellite imagery and field observations, the different features of this ancient landscape were identified as well as the lithology and fabric of the volcanic and pyroclastic rocks, which were petrographically studied. Textural transformations occurring in ignimbrites provided properties to these rocks which are similar to those common in granitic rocks. The studied landforms might be regarded as pseudo-granitic landforms, and thus major and minor landforms are described. Fracturing has been found as a significant factor in landform evolution.
\end{abstract}

Keywords Gondwana • Argentina • La Pampa • Ignimbrites • Granitic geomorphology

E.Y. Aguilera $(\square)$

Facultad de Ciencias Naturales y Museo, Universidad Nacional de La Plata (UNLP),

Calles 122 y 60, 1900-La Plata, Argentina

DAIS (Dirección de Aplicación de Imágenes Satelitarias), Calle $7 \mathrm{~N}^{\circ} 1267-2^{\circ} \mathrm{P}$,

1900-La Plata, Argentina

e-mail: eaguilera@fcnym.unlp.edu.ar

A.M. Sato • E. Llambías

Centro de Investigaciones Geológicas (CIG), CONICET-UNLP, 1900 La Plata, Argentina

H. Tickyj

Departamento de Ciencias Naturales, Facultad de Ciencias Exactas y Naturales, Universidad Nacional de La Pampa, Avda. Uruguay 151, L6300CLB, Santa Rosa, La Pampa, Argentina 


\section{Introduction}

Paleosurfaces are relict topographic surfaces corresponding to ancient surfaces of regional extent. As a consequence of their evolution, they record the effects of surficial alteration which have been the result of very long periods in which weathering, erosion, or no-deposition alternated (Widdowson 1997). Their importance is based upon the fact that they are key geomorphological elements in the long-term landscape evolutionary reconstruction.

The Sierra de Lihuel Calel (i.e., the Lihuel Calel hilly ranges) raise above the ignimbritic plateau which composes $\left(45 \mathrm{~km}^{2}\right)$ pat of the Chadileuvú Block (see Zárate and Folguera 2014, this volume), in the province of La Pampa, Central Argentina. According to Ramos (1999), this region would have maintained a relatively stable position during most of the Mesozoic and Cenozoic, thus being subject of "prolonged peneplainization." The ignimbritic plateau is characterized by a smoothly undulating topography, with the exception of the Sierra de Lihuel Calel which rise above the surrounding plains as if it was a large-scale inselberg. It is composed of a thick sequence of ignimbrite beds, coarsely stratified, of an approximate $\mathrm{N}-\mathrm{S}$ strike, and inclinations varying between 20 and $25^{\circ}$. The erosion patterns reflect erosion processes in the long term, probably periods of up to $200 \mathrm{Ma}$, possibly as a response to extensive exposition to atmospheric and climatic conditions. This investigation aims to characterize the landforms of the ignimbrite landscape found in these Sierras, where the nature, texture, and structure of ignimbrites have conditioned and affected the resulting landforms.

The methodological criteria proposed by Twidale $(1982,1983)$ and Vidal Romaní and Twidale (1998) were followed in the different steps leading to the analysis of this landscape developed exclusively on ignimbrites, paying special attention to the varying size and scale of the different landforms found in these landscapes. This study has started at the scale of the paleosurface developed on top of the ignimbrite plateau, identifying different sets of major and minor landforms.

\section{Study Area}

The Sierra de Lihuel Calel are located in the province of La Pampa, Central Argentina, centered around $38^{\circ} 00^{\prime}$ lat. S and $65^{\circ} 36^{\prime}$ long. W (Fig. 1). The sierras are crossed by National Route 152 . This range is the highest topographic feature found in the immense, semidesert plains of this region, characterized by large salt lakes in a very arid country. The Sierra de Lihuel Calel are part of the Lihuel Calel State Park, which has abundant autochthonous flora and fauna and cultural heritage, such as noted rock art. 


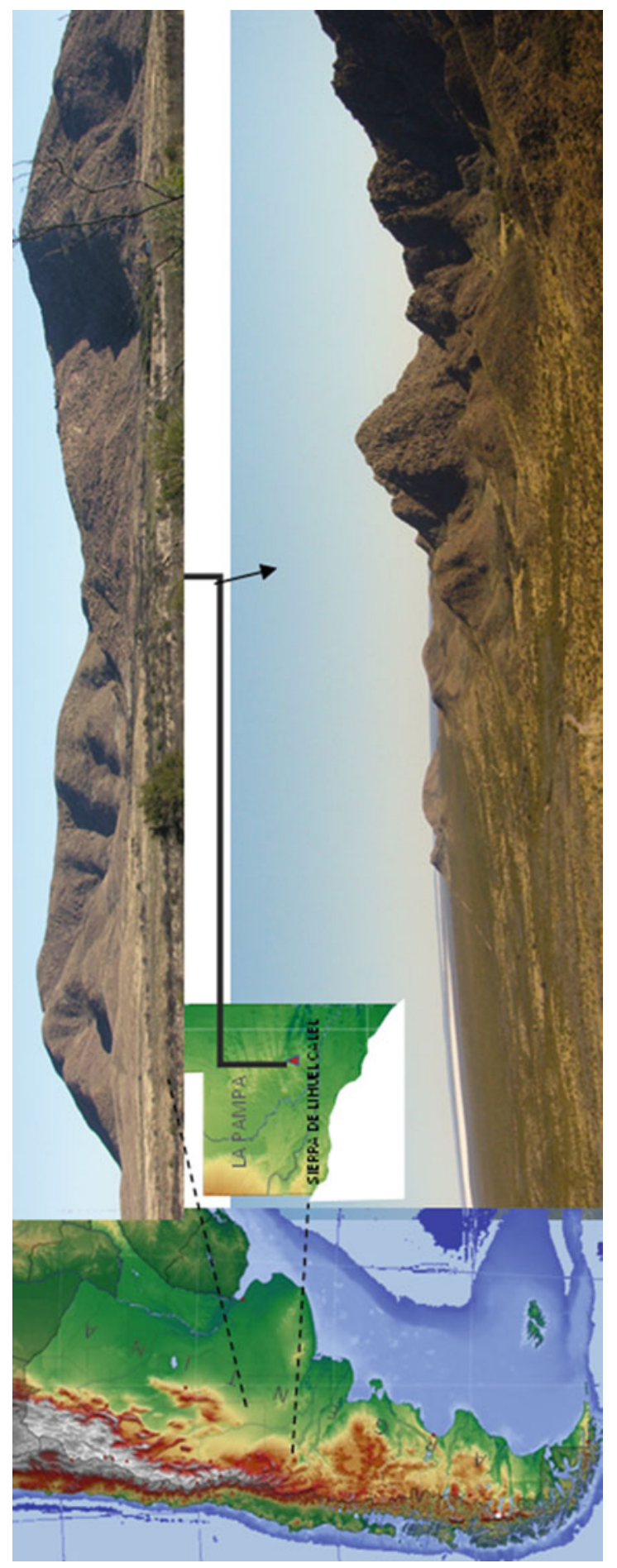

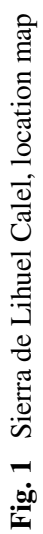




\section{Methodology}

Those factors intervening in the genesis and evolution of the ignimbrite landforms were identified and described and later interpreted by means of field observations, joint density analysis, and orientation of fracture alignments using satellite imagery. Landsat, Google Earth, and SRTM (Shuttle Radar Topography Mission) images and DEM (digital elevation models) were used in this investigation. These materials were operated using GIS (geographic information systems), which were used as a base for the geological and geomorphological studies, the qualitative and quantitative analysis, and the gathering information to be included in topographic sections.

\section{Geological Setting}

The Sierra de Lihuel Calel are mainly composed of a sequence of rhyolitic ignimbrites (Llambías 1975; Sruoga and Llambías 1992), which are part of a more extended rhyolitic plateau, of Permian to Early Triassic age that covers most of the province of La Pampa (Llambías and Leveratto 1975). The ignimbrites overlie the basement integrated by igneous and metamorphic rocks of Late Proterozoic to Early Paleozoic age (Linares et al. 1980; Tickyj et al. 1999; Sato et al. 2000).

The thickness of the ignimbrite units of the Sierra de Lihuel Calel exceeds $950 \mathrm{~m}$ (Fig. 2), but neither the base nor the top is exposed. The ignimbrite beds are homoclinally dipping to the WNW, with values close to $25^{\circ}$ at the basal levels and values closer to $15^{\circ}$ observed in the uppermost beds (Fig. 3). This thick sequence is composed of two cooling units, both of rhyolitic composition: the lower one, with a thickness of $440 \mathrm{~m}$, and the upper one, with more than $450 \mathrm{~m}$ thick (Sruoga and Llambías 1992). The lower one overlies very thin flows, which as a whole are no more than $20 \mathrm{~m}$ thick and which are composed of highly welded, rhyolitic ignimbrites and volcanic breccias. The upper cooling unit is separated from the lower one by a thin cooling unit up to $50 \mathrm{~m}$ thick, composed of highly welded dacitic ignimbrites. Sruoga and Llambías (1992) attributed the large thicknesses of the two cooling units to the process of infilling of a volcanic caldera.

The age of the Lihuel Calel ignimbrites has been determined by means of $\mathrm{Rb}-\mathrm{Sr}$ isochrones at $238 \pm 5 \mathrm{Ma}$ by Linares et al. (1980) and at $240 \pm 2$ Ma by Rapela et al. (1996). After the intense volcanic activity during the Permian and Triassic, there was no further magmatic activity in the area. Moreover, these rocks were never covered by marine strata since the Paleozoic. It was only in the Late Miocene that the whole complex was covered by a thin veneer of continental sedimentary rocks, whose top shows a highest elevation of only $285 \mathrm{~m}$ a.s.l., a reason for which the Sierra de Lihuel Calel were never entirely covered by these sediments. 


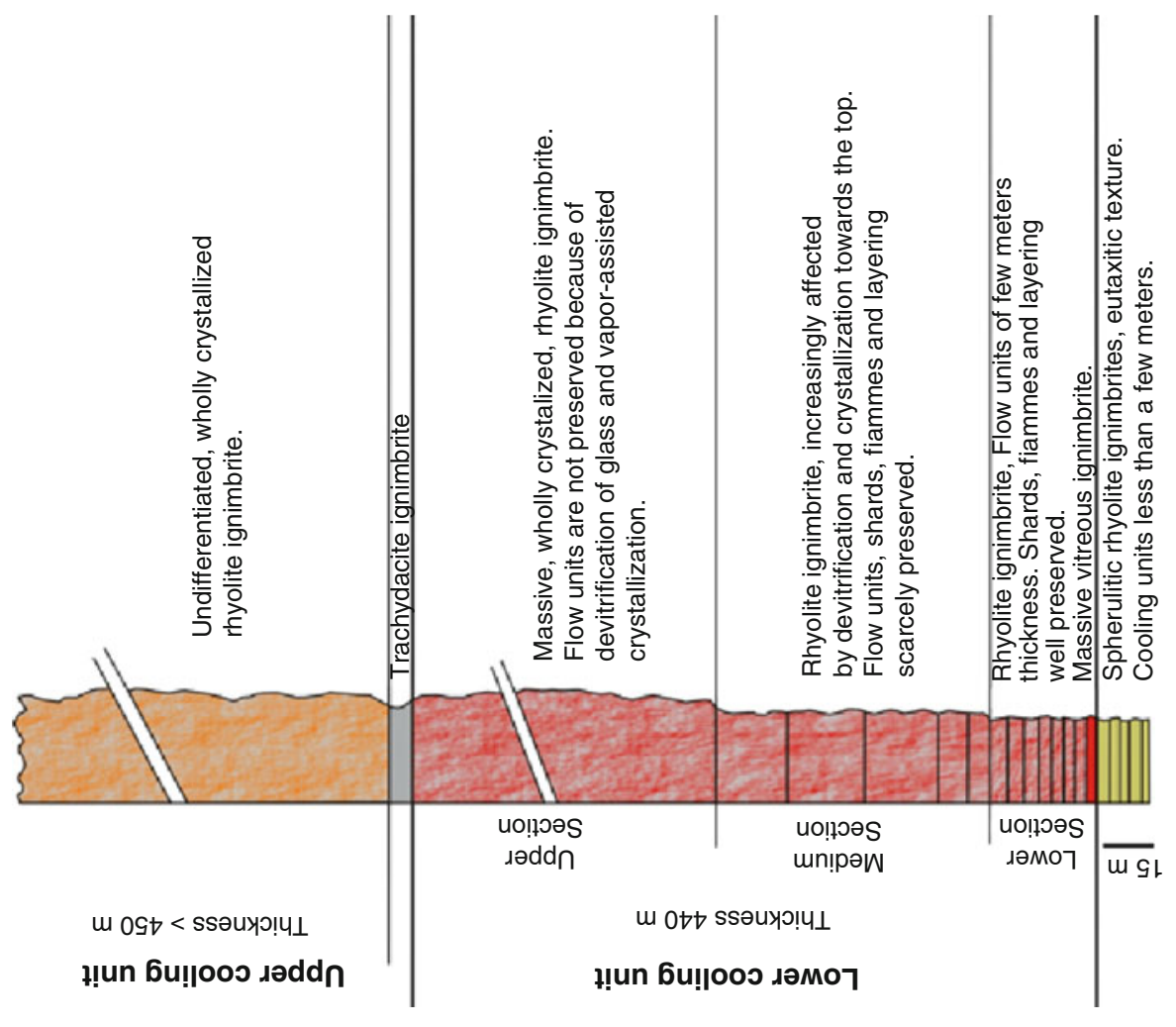




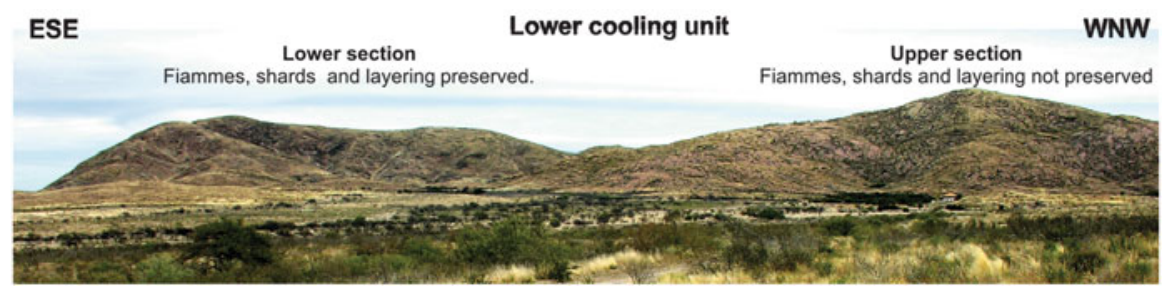

Fig. 3 View of the Sierra de Lihuel Calel from north to south, indicating in the cooling unit the sectors in which the fiammes, shards and layering are preserved

These continental sediments belong to the Cerro Azul Formation (Llambías 1975). This unit is composed of silts, sandy silts, and very fine, silty sands, with abundant calcium carbonate nodules and strong evidence of pedogenetic processes. It is bearing a varied suite of fossil vertebrate of Late Miocene age. These are aeolian deposits characterized by loess-like fine materials, with interbedded paleosols (Folgueras and Zárate 2009). Due to the change of the subduction angle and the plate convergence, which took place between the end of the Late Miocene and the Early Pleistocene, a significant change in the environmental conditions took place, which has been recorded by the sediments of the Cerro Azul Formation.

The Lihuel Calel ignimbrite plateau is the product of the Gondwana silicic magmatism, and it became installed within a predominantly extensive environment, superimposed to a previous compression event associated to the thickening of the crust and orogenic uplifting (Sruoga and Llambías 1992). The Sierra de Lihuel Calel represent one of the topographic highs of the ignimbrite plateau (Llambías 1973).

\section{Ignimbrites}

\section{Most Relevant Characteristics}

Ignimbrites are pyroclastic flow deposits, which are composed of vitroclasts, crystalloclasts, lithic components, pumice, and gas. The ignimbrite bodies have variable thickness, both in vertical and lateral directions, according to several conditions, such as underlying topography, crystalloclast, pumice, lithic clasts, and rock density. The large volume of ignimbrite eruptions may produce flooding of the landscape forming extensive plateaus. The pyroclastic flows are complex volcanic units, with a large variety of intervening processes in their formation, and they are chaotically deposited due to the violence and speed of the eruptive style. These characteristics are recorded in the large spectrum of observed facies occurring in the pyroclastic deposits.

When referring these rocks as ignimbrites, reference is made to their texture and the kind of depositional process but not to their chemical or petrographic composition. Thus, the composition must be included in the description, for instance, rhyolitic, dacitic, or andesitic ignimbrite (Llambias 2003). 
The processes accompanying the deposition such as compaction, cooling, and crystallization during the vapor phase may introduce major textural changes. The high temperature (over $550{ }^{\circ} \mathrm{C}$ ) of these flows frequently produces the welding of these deposits, though sometimes these units do not show evidence of welding. Welding takes place by agglomeration and deformation of the vitroclasts. The welded ignimbrites have eutaxitic texture, which is a product of pumice deformation.

Welded ignimbrites cool out as a homogeneous material and usually they exhibit columnar jointing, and less frequently, joints occur in the unwelded zones. Jointing takes place due to thermal contraction. Generally, the joint separation varies from a few centimeters to one meter. This variation is directly related to the degree of welding, whereas the wider jointing is related to lesser degrees of welding, whereas a closer jointing is associated with intense welding. Another factor that has influence on the joint separation is the cooling rate, where a wider spacing would reflect a slower cooling rate (Wilson 1993). For instance, in the volcanic province of Cappadocia, Turkey, which is characterized by large ignimbrite deposits of varied thickness and welding degree, columnar jointing is found even in the non-welded zone, which extends towards the uppermost zone, where strange erosion landforms, such as "fairy chimneys," villages, monasteries, and churches, are developed (Ollier 1988). Jointing has also been recognized in welded ignimbrites such as the Bishop, Tuffs, or Bandelier ignimbrites, where joints are frequent in the upper non-welded zone and the vapor phase has been channelized along these fractures, altering sectors of the units. However, in the basal portions of these ash flows the joints are absent. For example, in the Taupo ignimbrite plateau, New Zealand, where pumice deposits developed a landscape characterized by rounded hills, when the ignimbrite-welded zone is exposed, it generates bare rock vertical cliffs, following the joint systems. It is common that the upper pumice zone is removed by erosion. In this case, the welded ignimbrite acts as the cap rock, developing mesas, tables, and buttes. These landforms evolve towards ignimbrite tors by size reduction, which are typical of the North Island of New Zealand. The Mamaku Plateau of New Zealand covers an area of $1,500 \mathrm{~km}^{2}$, approximately. The tor development may be the result of different degree of welding, which may vary in short distances and favor the differential erosion (Ollier 1988), being the joint spacing in the ignimbrite flows determined by the degree of welding as well.

\section{Petrography}

The landforms herein described belong to the middle and high portions of the welded ignimbrite, where the original eutaxitic texture is modified by devitrification and/or crystallization processes assisted by vapor phase, which produced a porphyritic texture, with noticeable crystalloclasts as "phenocrysts," surrounded by a groundmass varying between microcrystalline (grain size from 4 to $63 \mu \mathrm{m}$ ) and very 
fine-grained (from 63 to $125 \mu \mathrm{m}$ ) to fine-sized crystalline (from 125 to $250 \mu \mathrm{m}$ ). It is possible to follow the continuous upward variation in the recrystallization texture of the ignimbrite.

In the basal portion of the ignimbrite (a few tens of meters), the eutaxitic texture that results from compaction and flattening of pumice fragments is significant, with elongated "fiammes" of up to $2 \times 10 \mathrm{~cm}$ (Fig. 4a, b). Between 20 and $25 \%$ of the crystalloclast, characterize this section with quartz, acid plagioclase, and sanidine, in that order of abundance, in addition to scarce, altered lithoclasts of acid volcanic rocks. The fiammes show spherulitic devitrification, with interlocking open spherulites of fan to bow-tie types (following the terminology by McArthur et al. 1998), with fiber length of up to $100 \mu \mathrm{m}$, and sweeping extinction. Sectors with very fine crystal aggregates of clean quartz feldspar would correspond to crystallization starting in vapor phase in the original vesicles. Welded glass shards in the vitroclastic matrix are aligned in bands and slightly deformed at the crystal margins. They present devitrification to a cryptocrystalline to fine-grained crystalline aggregates, of less than $10 \mu \mathrm{m}$ in grain diameter (Fig. 4c, d).

In the following 50-100 m, the fiammes are fewer and less visible at the microscopic scale, although lenses of texture different to that of the matrix are microscopically distinguished as lenses of texture are clearly different from that of the matrix. They are elongated and undulating dominium, with wispy to ragged terminations, with inner spherulitic texture and axiolithic margins, and with coarser grain size upwards, which are transformed into granophyric to graphic aggregates (Fig. 4e, f). The quantity of crystals and lithoclasts is larger than $35 \%$, and they are composed of quartz, sanidine, plagioclase, and, to a lesser extent, opaque or mafic minerals. The volcanic lithoclasts are scarce, showing sporadic distribution. The matrix is crystallized into a felsitic, very fine-grained crystalline aggregate, in which minute nuclei of biotite and fluorite are observed. The shape of the preexisting vitroclasts may be recognized at plain polarized light.

In a stratigraphical position above the previously described units, the middle sections of this cooling unit which are relevant to this chapter are placed. The fiammes are not visible in the outcrops of this section, with the exception of very sporadic, centimeter-long lenses distinguishable by a darker coloration. In the matrix, it is not possible to identify the dominium corresponding to fiammes, because the texture is inhomogeneous and with irregular sectors bearing very fineto fine-grained crystalline aggregates, passing to quartz, feldspar, and biotite clean aggregates, in which fluorite, epidote, and opaque minerals participate in a lesser proportion. In the sectors with finer aggregates, the matrix presents micro-poikilitic growth of quartz, feldspar, biotite, and scarce amphibole, including microcrystalline to very fine-crystalline grains, forming micro-poikilitic mosaics of sizes between 100 and $200 \mu \mathrm{m}$ (Fig. 4f). Likewise, the crystals of quartz, sanidine, and plagioclase show overgrowth along their margins, at the expense of the finer matrix (Fig. $4 \mathrm{~g}, \mathrm{~h}$ ), which stay as inclusions that still depict the preexisting crystalline margins. The modal counting of the crystals, without their poikilitic growth rims, indicates around $40 \%$ adding quartz, sanidine, and plagioclase, with lesser proportion of opaque minerals and allanite. Along the entire profile, the quartz crystals appear as 

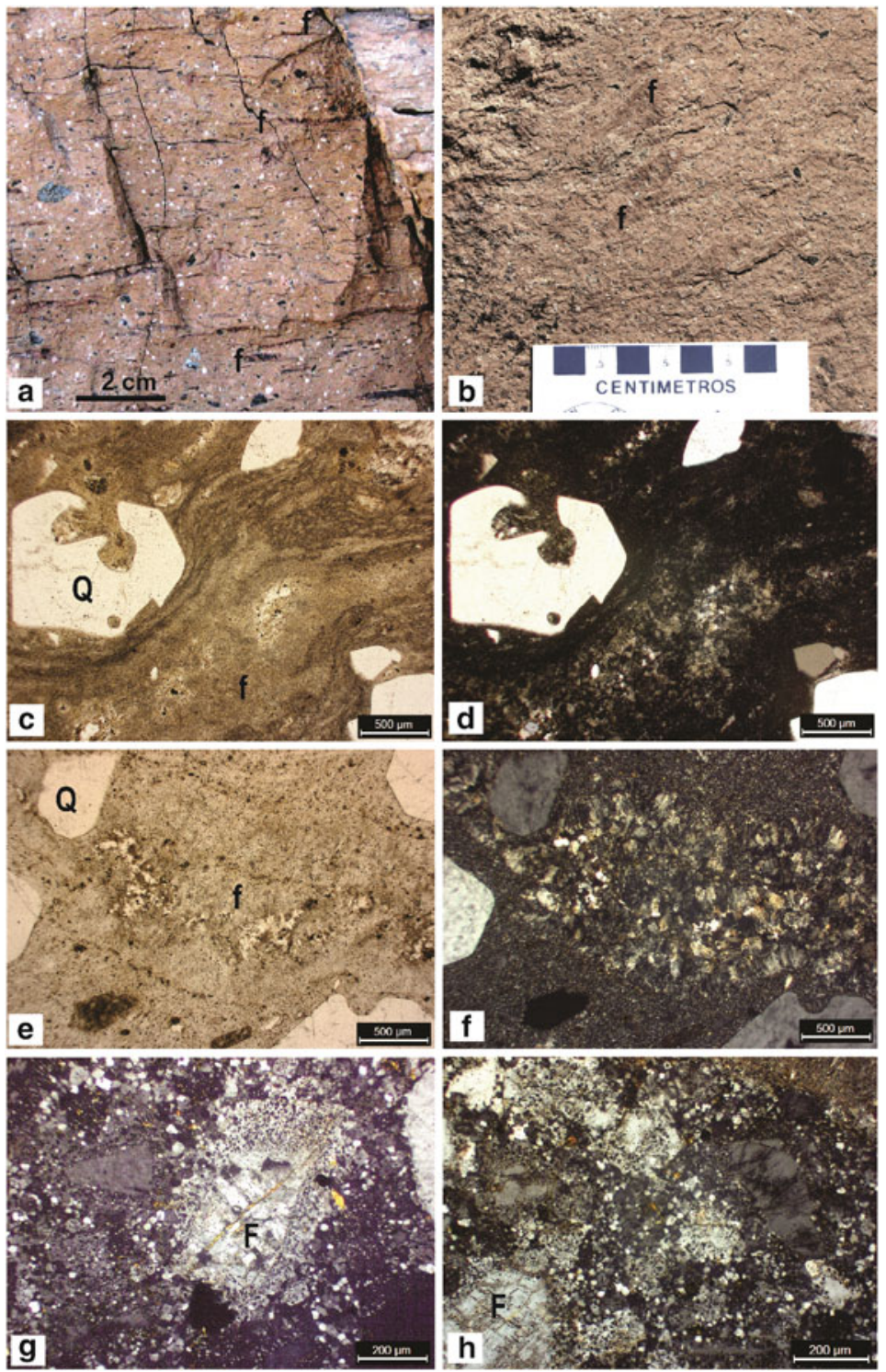

Fig. 4 (a) Eutaxitic texture defined by thin lenses of fiamme, with mm-scale quartz, feldspar, and lithic clasts. Ignimbrite from the basal layers. (b) Thicker lenses of fiamme, few meters above the former ignimbrite. (c) Fiamme with ragged end and flattened glass shards wrapping around quartz crystals. Plane polarized light. (d) Same view as (c), with crossed nicols. Fiamme with incipient spherulitic devitrification and vitroclastic to cryptocrystalline matrix. (e) Fiamme is recognized as a lens-shaped domain containing clean quartz-feldspar aggregates. Plane polarized light. (f) Same view as (e), with crossed nicols. Spherulitic textures of the fiamme are transformed into coarser granophyric aggregates. Matrix is very finely crystalline felsitic aggregate. (g) Poikilitic overgrowth of feldspar crystal enclosing surrounding smaller grains of the matrix. Crossed nicols. (h) Micro-poikilitic texture formed by patches of quartz and feldspar in the matrix, enclosing smaller grains of the former felsitic aggregates. Crossed nicols. $f$ fiamme, $Q$ quartz, $F$ feldspar 
fragments, with subhedral or hexagonal trending shapes, with conspicuous engulfed margins, and also of skeletal pattern. Feldspar crystals are fragmentary, euhedral to subhedral, and with documented engulfments, which present a varied degree in albitization.

In this manner, the volcaniclastic origin of this cooling unit, very well preserved at the basal ignimbrite levels, remains erased upwards by devitrification and/or crystallization assisted by vapor phase, as suggested by the late crystallization of biotite and fluorite. Both the fiammes and the vitroclasts have been transformed in very fine- to fine-grained crystalline aggregates, with additional micro-poikilitic growth, which transform them into a mosaic of high inner cohesion. Adding to this, the poikilitic overgrowth of the quartz and feldspar crystalloclasts provides the rock an even stronger cohesion and a "porphyritic" appearance, typical of a coherent igneous rocks (see terminology in McPhie et al. 1993), as could be a sub-volcanic or plutonic intrusive body.

\section{Fractures}

The directions and length of major fractures were measured on satellite imagery and their influence on the erosion of the plateau was analyzed. The preferred regional direction of fractures is NW/SE and ENE/WSW, and some directions such as NE/SW are locally important.

Concerning the joints and according to their genesis, those directly related to regional tectonics are recognized in systems, which show a geometric pattern in which two joint systems are intercrossed (Fig. 6a). Other systems are composed of sets of parallel joints which are linked to the emplacement and cooling of the rocks.

Fracturing took place in various degrees in different sectors of the Sierras. The ignimbrite beds are stratified in layers of strike NNE/SSW, with inclinations of 20$25^{\circ}$. Bedding is partially obliterated by the development of dense perpendicular jointing. In the Cerro Lihuel Calel (Fig. 5) columnar jointing is found, where their spacing is of centimeter scale.

In other sectors, the deposits occur with very intense fracturing, with development of various systems of subvertical joints superimposed to columnar jointing. The upper level is characterized by poorly preserved columnar jointing, since it occurs in well-developed rounded shapes, whose bases exceed $2 \mathrm{~m}$, occasionally with horizontal partition in the upper and basal portions of these blocks, which may be related to flow plane jointing.

Unloading joints are not ruled out, because more than $450 \mathrm{~m}$ of ignimbrites accumulated on top of the studied levels, within the ancient caldera (intra-caldera ignimbrites). The upper portion was eroded after it was tilted up to $20^{\circ}$. The age of the tilting is unknown. During the tilting the NW/SE and ENE/WSW fractures were generated and also others following some other directions such as NE/SW. During erosion processes, the subcircular pattern joints may have been generated (Fig. 6b). This type of fracturing could have controlled later on the development of "nubbins" and tors. 

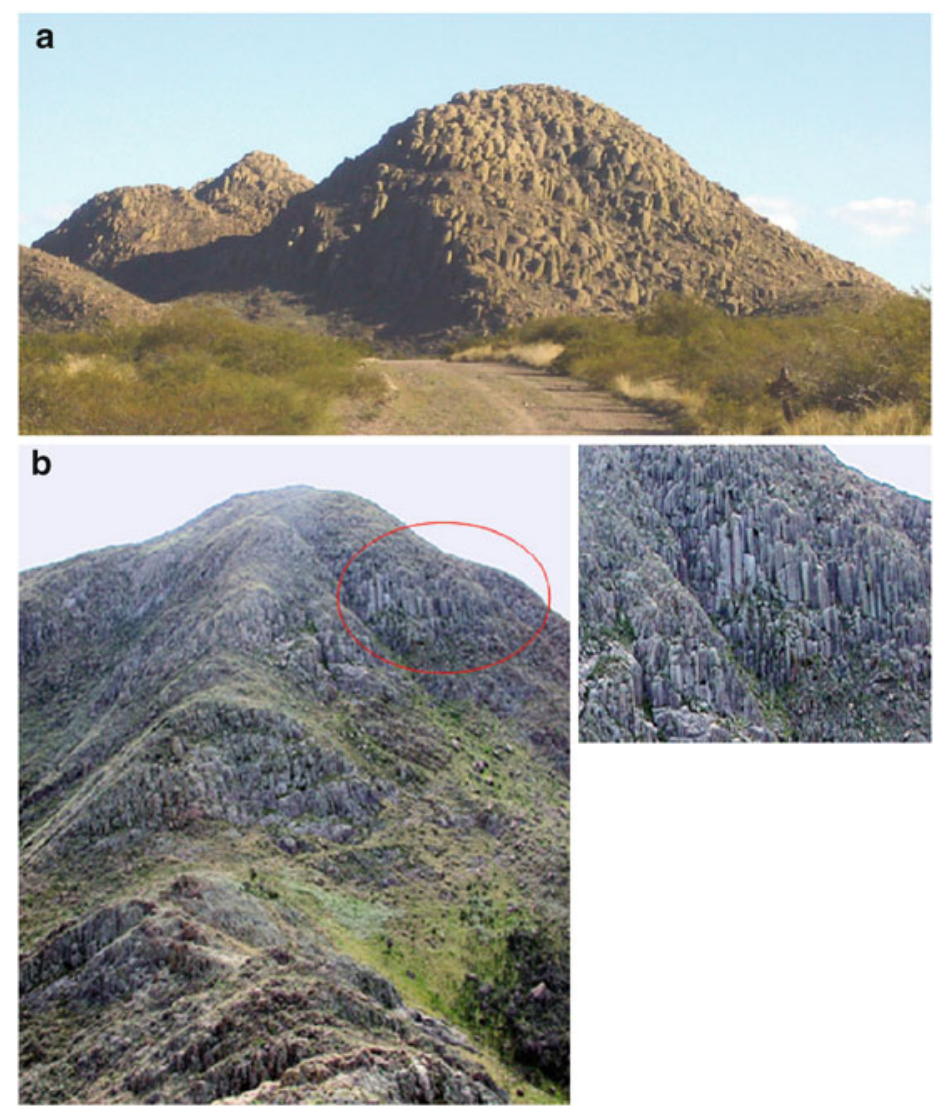

Fig. 5 (a) View from the north of Cerro Lihuel Calel, where the stratification with inclination to the west is observed, cut by perpendicular jointing. (b) Another mountain showing columnar jointing in a good degree of preservation

As a consequence of the elimination of the upper cover by erosion, changes in the stress and deformation conditions would have taken place. Towards the upper levels, the rocks would have developed a denser fracturing pattern, a product of the load removal and discharge expansion. The rocky bodies were thus fragmented by this fracturing network, which became later on penetration pathways for the weathering/denudation agents affecting the ignimbrites.

\section{Ignimbrite Inselberg Landscapes}

The isolated ranges of the Sierra de Lihuel Calel constitute an inselberg landscape, in which noted inselbergs are rising abruptly from the monotonous Pampean plains (Fig. 7a). These inselbergs are surrounded by pediments which may be differentiated 


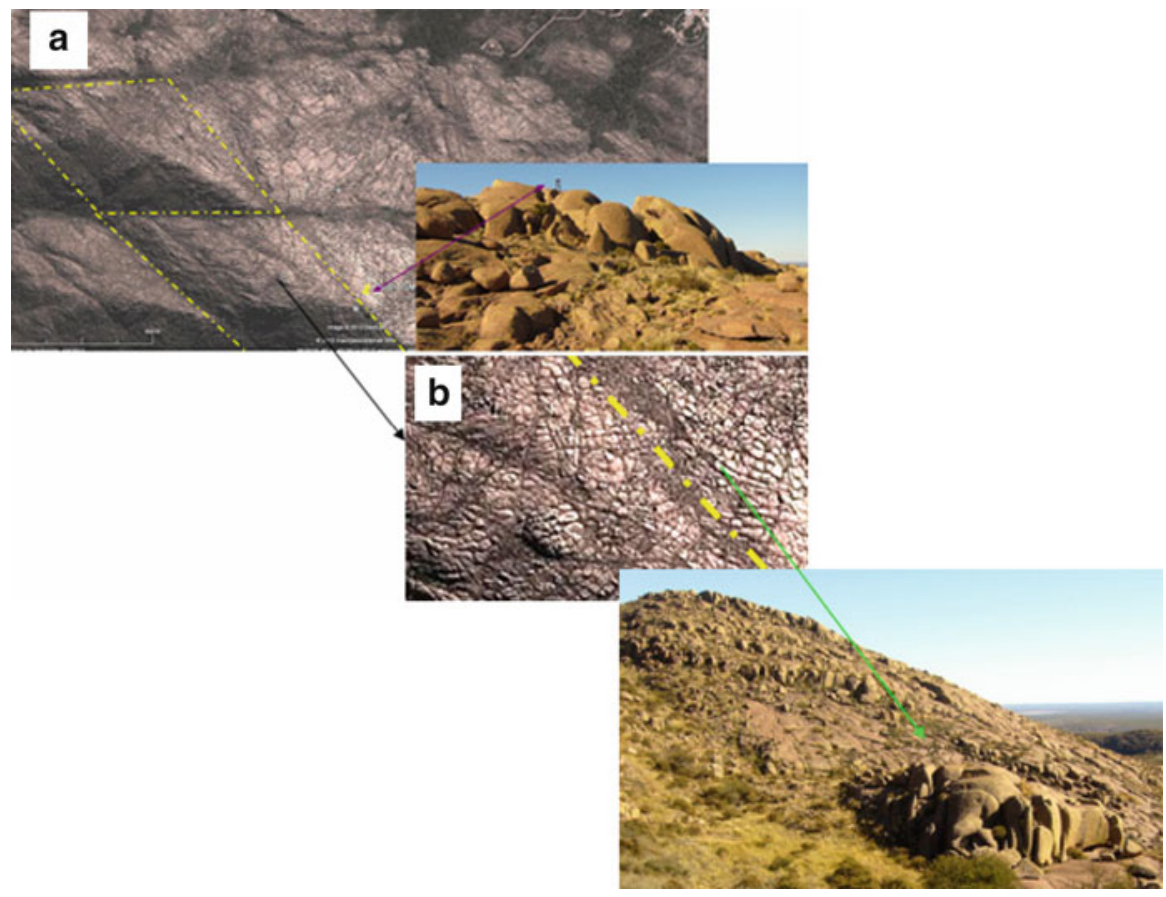

Fig. 6 Fractures of varying order of magnitude, seen in GeoEye/Google Earth image and field photographs. (a) In yellow, the crossing of two sets of major joints related to basement tectonics. (b) Enlargement of the same image in which numerous minor fractures with subcircular geometry may be observed

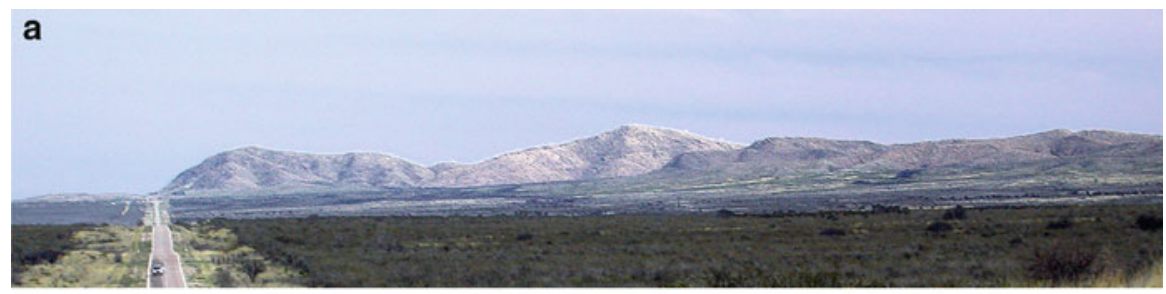

b

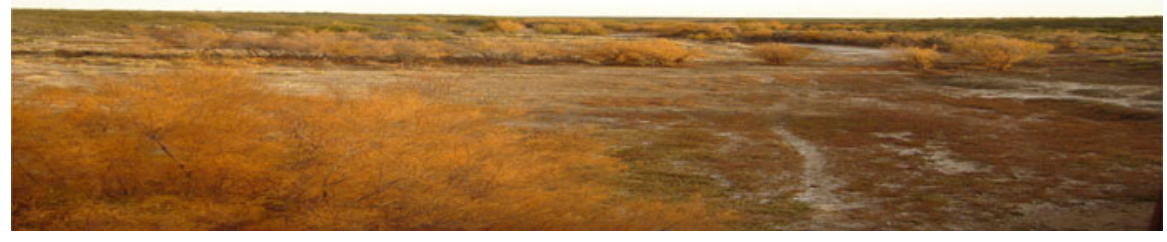

Fig. 7 (a) Plain, surrounding the Sierra de Lihuel Calel (inselberg). This landform is characterized by the alternation of highs and depressions (see the undulating road). (b) View of a sector of the plain, crossed by an ephemeral stream 
from the plain itself. These pediments are usually covered by regolith. The regolith is a mantle-like deposit, with rounded to subangular, ignimbrite clasts, with a reddish sandy matrix. The clasts have a maximum size range between 5 and $10 \mathrm{~cm}$. Underlying these materials and in contact with the fresh ignimbrite, a reddish weathered zone is observed, which is easily disintegrated when hit with the geological hammer.

The inselbergs themselves are domes of bare rock. Their morphology is varied, from elliptically elongated and low whaleback type to true domes whose dimensions in length and height are practically equal. Some inselbergs occur in groups. Individual domes are developed from huge joint blocks. The evolution of inselbergs is accompanied or followed by formation of other landforms, such as corestones, nubbins, and castle koppies.

The question arises whether the inselbergs were formed by intense chemical weathering and stripping or by fluvial erosion and slope retreat-forming pediments and pediplains.

The ignimbrite mantles are easily weathered when they come in contact with circulating waters. This is favored by its mineralogical composition in which feldspar is one of the more abundant components. They present a fracturing pattern similar to that of granitic rocks, that is, an orthogonal joint system, and other randomly oriented fractures as well as numerous micro-fissures (Vidal Romaní and Twidale 1998). The rocks of the Sierra de Lihuel Calel have been exposed to atmospheric and underground waters over a very long time period. Deep weathering and erosion have lowered the relief of the area, with the development of a regolith cover and immediately below it a weathering front. As a consequence of the denudation of the regolith cover, the weathering front has become exposed at the surface, and the plain can be regarded as an etchplain.

\section{Landform Identification}

The landforms, of all sizes, are interpreted as having had a sub-superficial origin, since they are developed at the weathering front (Mabbutt 1961). Among the larger landforms, the following features may be recognized: the regional plain and inselbergs, domes, nubbins, castle koppies and tors.

The regional plain is located surrounding the Sierra de Lihuel Calel. This landform is characterized by the alternation of elevations and depressions, a very smooth relief, and a discontinuous regolith cover. Towards the east, the plain gradually loses elevation, following the regional slope, and provides certain monotony to the landscape. It constitutes a planation surface or an erosion surface, in the sense of Ollier (1991). See Figs. 7a, b, 8, and 9.

In the representation of the topography of the study area (Fig. 8), a local base level is observed in between the 202 and $242 \mathrm{~m}$ contour lines. It is a topographic level with smooth undulations and frequent presence of lakes, ponds, and salt lakes. The fluvial channels of ephemeral nature discharge towards the La Amarga, Urre 

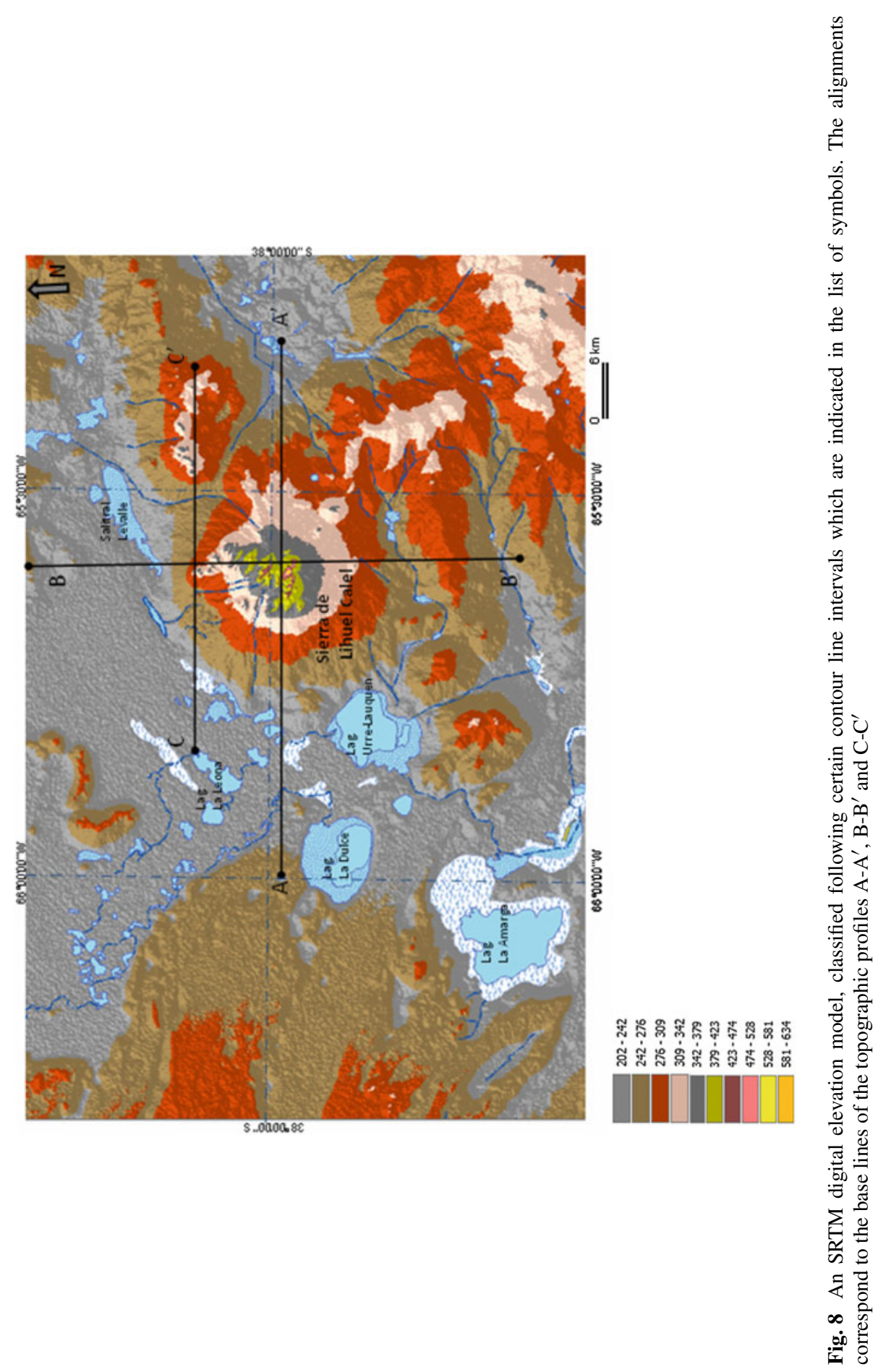


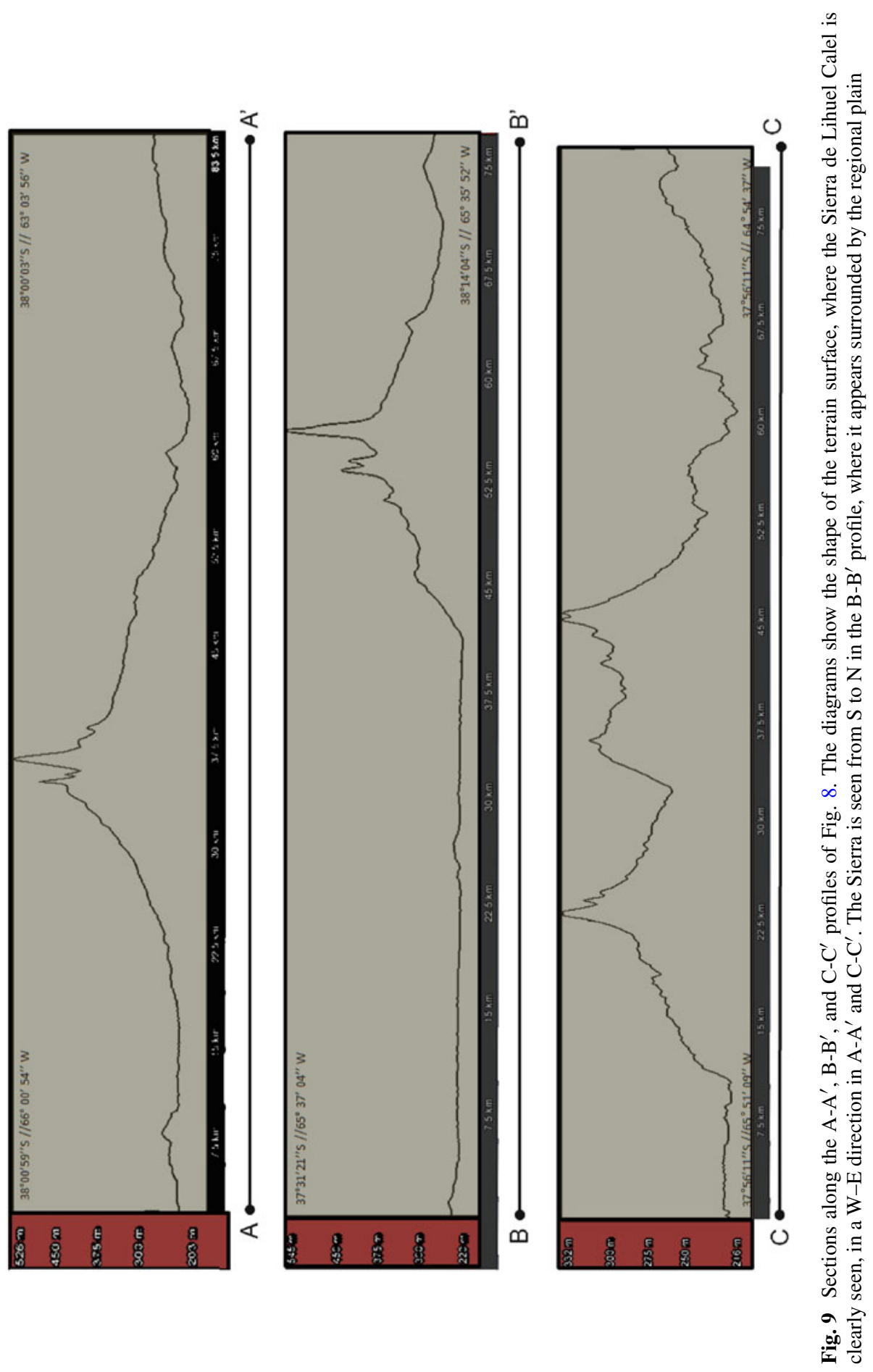




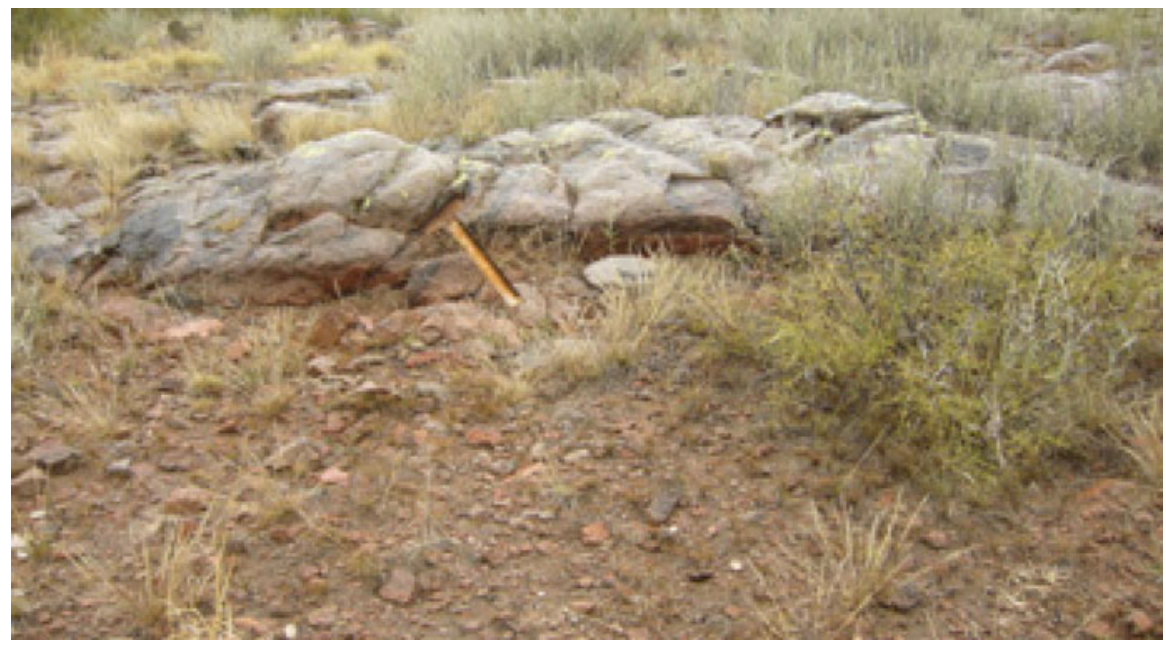

Fig. 10 All the unconsolidated materials compose the regolith cover in which fresh rock, rounded boulders named as "corestones," occur

Lauquen, La Dulce, and La Leona lakes and also in the Lavalle salt lake and others of smaller size. The contour interval between 242 and $276 \mathrm{~m}$ occupies the larger superficial extent in the Sierras, with a marked incision by small ephemeral streams, favored by the joint systems. At this level, the Cerro Cortado is located, whose summit scarcely exceeds the $300 \mathrm{~m}$ contour line. In the 276-309 m interval, a greater topographic dissection takes place, with a tendency towards dendritic stream pattern, as is the same in the gentler slopes towards the E/SE. The upper contour intervals clearly reflect an important areal reduction by denudation, with high incision. The maximum elevation is found at the Cerro de la Sociedad Científica (590 m a.s.l.).

The upper part of this unit has little soil development, but it is disturbed by plant roots and fossorial animals. The zone immediately below it is undisturbed and preserves the original structure of the rock as a saprolite. All the unconsolidated material composes the regolith cover in which fresh rock, round-shaped boulders, named as "corestones," occur (Fig. 10). This association of regolith and fresh rock corresponds to the ancient weathering front, which extends downwards below the surface.

Nubbins are dome-shaped, small hills, composed of boulders (Fig. 11). In the foreground a highly degraded dome occurs, with orthogonal fracturing, in some sectors with curved pattern and partly of the radial type. Nubbins (as a result of the in situ degradation of the dome) and rocky fields that are forming the debris at the foot of the dome are observed. At the background, the Cerro Cortado is located, where primary structures of the ignimbrite beds, with development of bedding, are observed (Fig. 11).

Inselbergs are relatively high and steep-sized hills, with dominant vertical jointing and subordinate curved jointing and the development of vertical walls which were cut by the curved fracture system (Fig. 12). 

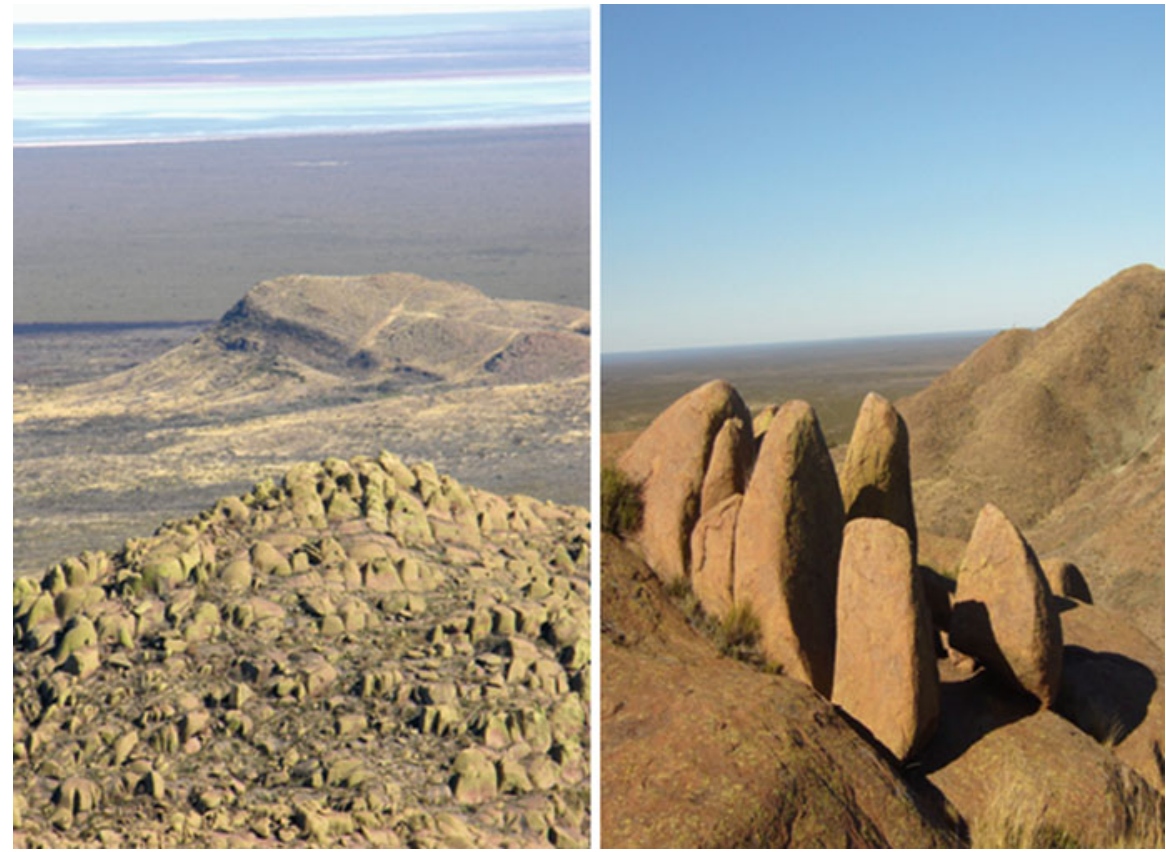

Fig. 11 Left image: curve jointing in dome landforms, associated to a vertical system with progressive development of nubbins at the foreground. At the background is the Cerro Cortado where primary structures of the ignimbritic beds are observed. Right image: development of nubbins in the sides of a dome

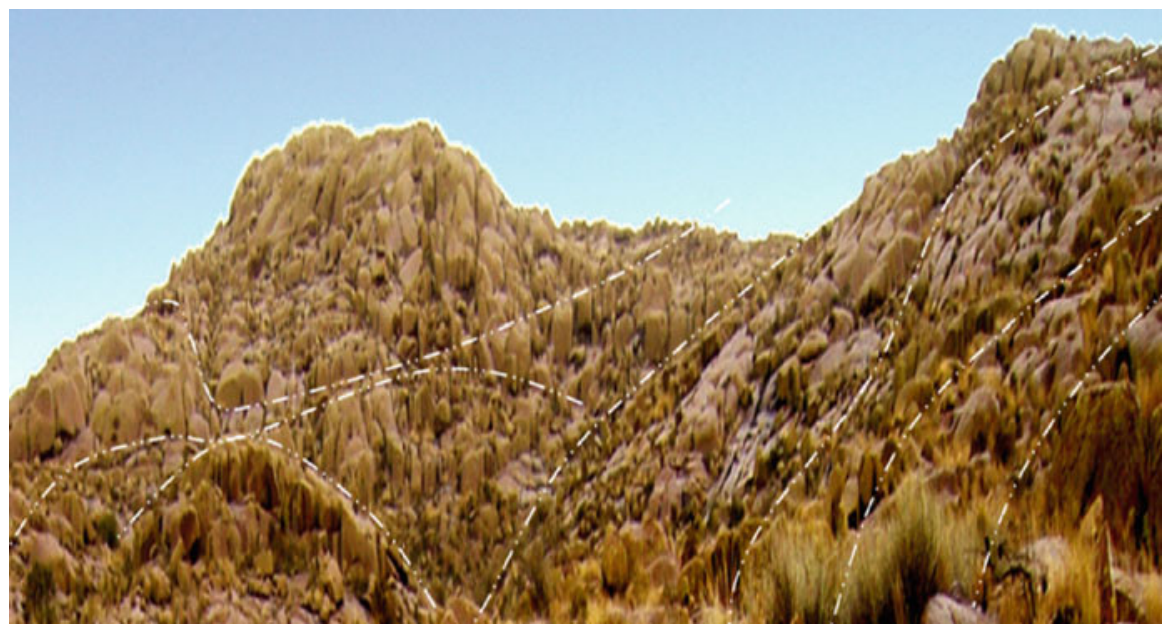

Fig. 12 Inselbergs with dominant vertical jointing and subordinate curved jointing 

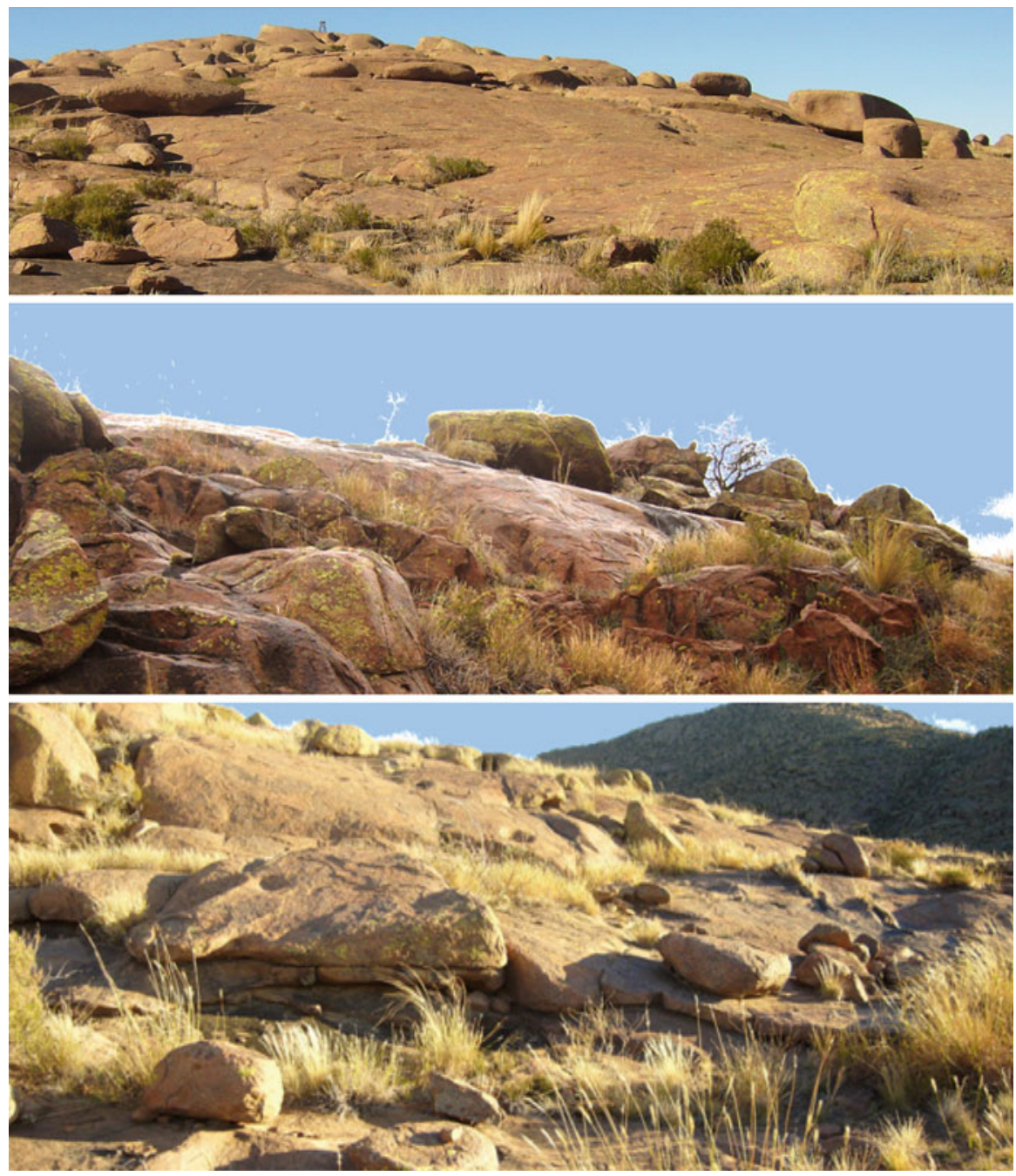

Fig. 13 Dome landforms of the whaleback type. Rocky surfaces shown are part of the flanks and tops of domes, either partially exhumed or in process of exhumation

Dome landforms of the whaleback type are developed at Cerro Alto, with curved jointing and degradation in nubbins and rocky fields that determine flat surfaces with subhorizontal jointing. Rocky surfaces are part of the flanks and tops of partially exhumed (or in process of exhumation) domes, which limit flat surfaces with horizontal to subhorizontal jointing. Favored by the slope inclination, the sliding of slabs or boulders feeds incipient stone accumulations (Fig. 13).

Castle koppies are domes whose morphology is controlled by fracturing systems. In them, orthogonal jointing is observed, limiting angular blocks. This type of dome 


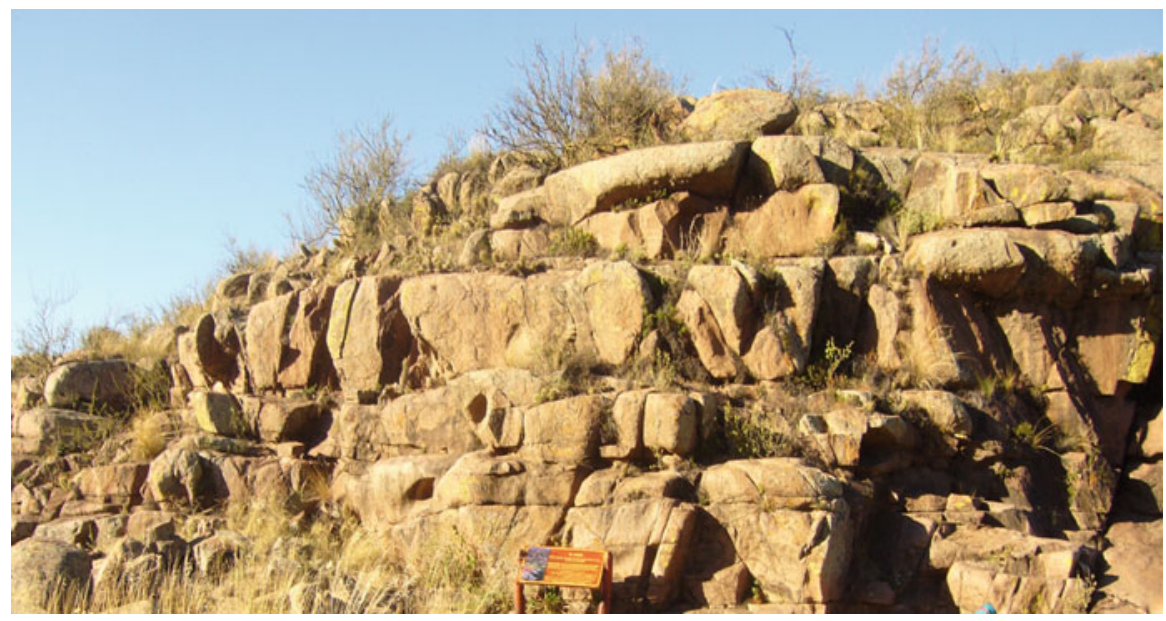

Fig. 14 Castle koppies limited by orthogonal joints, located in the Valle de las Pinturas (Arroyo de las Sierras)
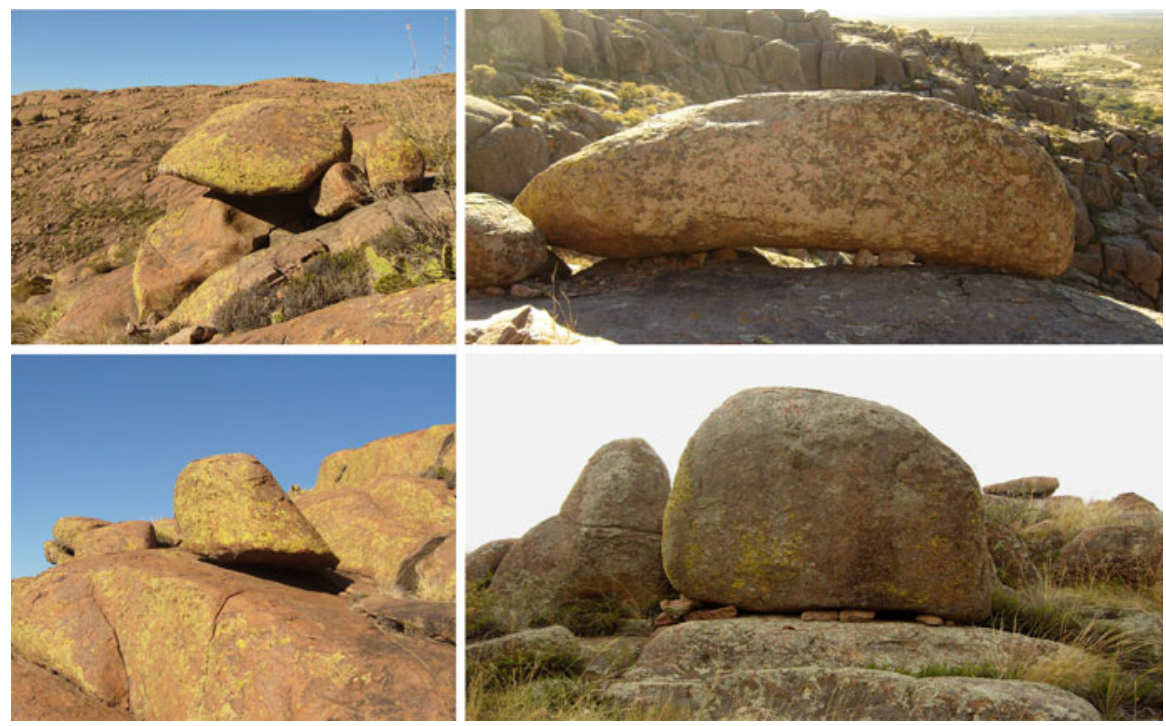

Fig. 15 Tors with varied morphology along the sides of Cerro Alto, where many slumped blocks are found, some of them could have been "rocking stones" in the past

has been given its name due to their likeness to castle shapes (Fig. 14). Horizontal and vertical joints are noted. The upper blocks show certain rounding with respect to the blocks at the base of the features, which are more angular.

Tors is the name given to rocky blocks limited by fractures, which occur disseminated in different areas, in various topographic levels and exhibiting multiple morphologies. Their basal portions are usually planar, oblique, or rounded (Fig. 15). 


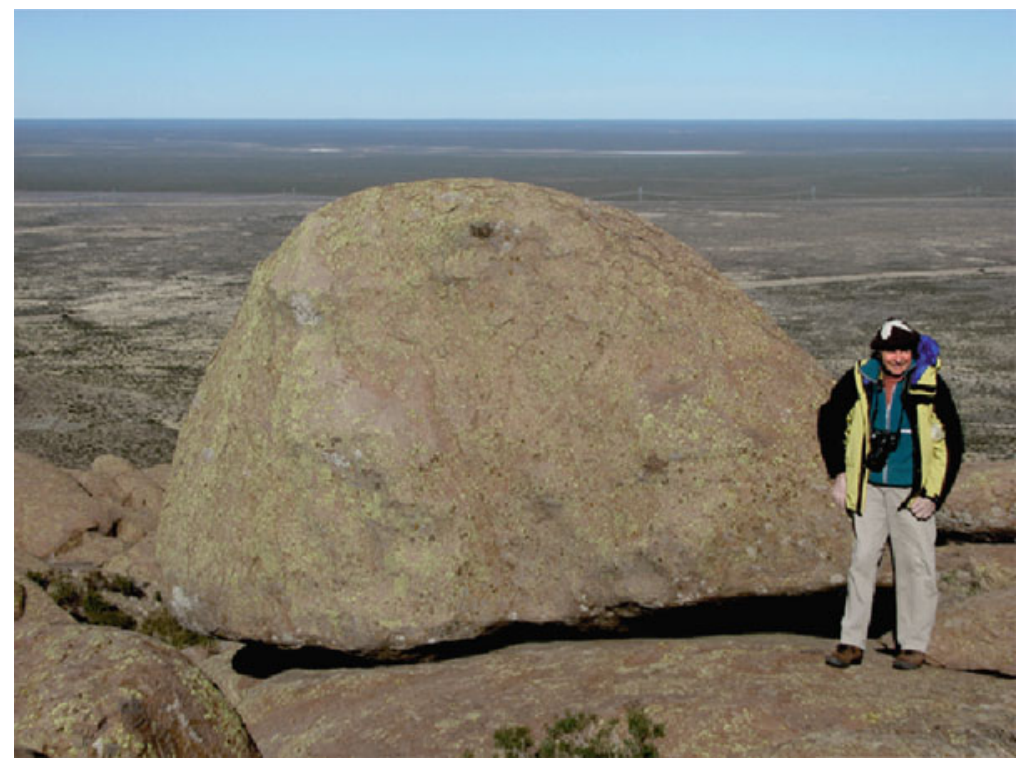

Fig. 16 "Rocking stone" ("Piedra Movediza") or balancing rock: block of several cubic meters. This rock is located $\mathrm{W}$ of the Cerro Alto and it is not balancing anymore, since its two pedestals were destroyed

They are normally found in groups, but isolated landforms also occur. There are examples of tors in unstable equilibrium, which are known as "balancing rocks" (Fig. 16).

Regolith zones are observed in very ample surfaces where nuclei of fresh rock may be detected as if they were submerged into regolith. It should be noted that the weathering and the dismantling of the regolith has been incomplete. The landscape is characterized by flat sections where it is interrupted by the outcropping of blocks, groups of boulders, nubbins, and castle koppies. The regolith is preserved in the lower zones where residual corestones are still outcropping. Strip-shaped zones are coincident with the boundaries between different flow units. The limits between units affected differentially the local weathering rate, resulting in a steplike topography (Fig. 17).

\section{Small-Scale and Minor Landforms}

Alveoli correspond from rounded to ellipsoidal holes, of centimeter size, which occur in groups. They merge altogether and in depth, they form larger cavities, sometimes separated by just thin walls. They appear in surfaces of medium to steep inclination. They may be found in the inner parts of rock cavities named as tafoni (Fig. 18). 


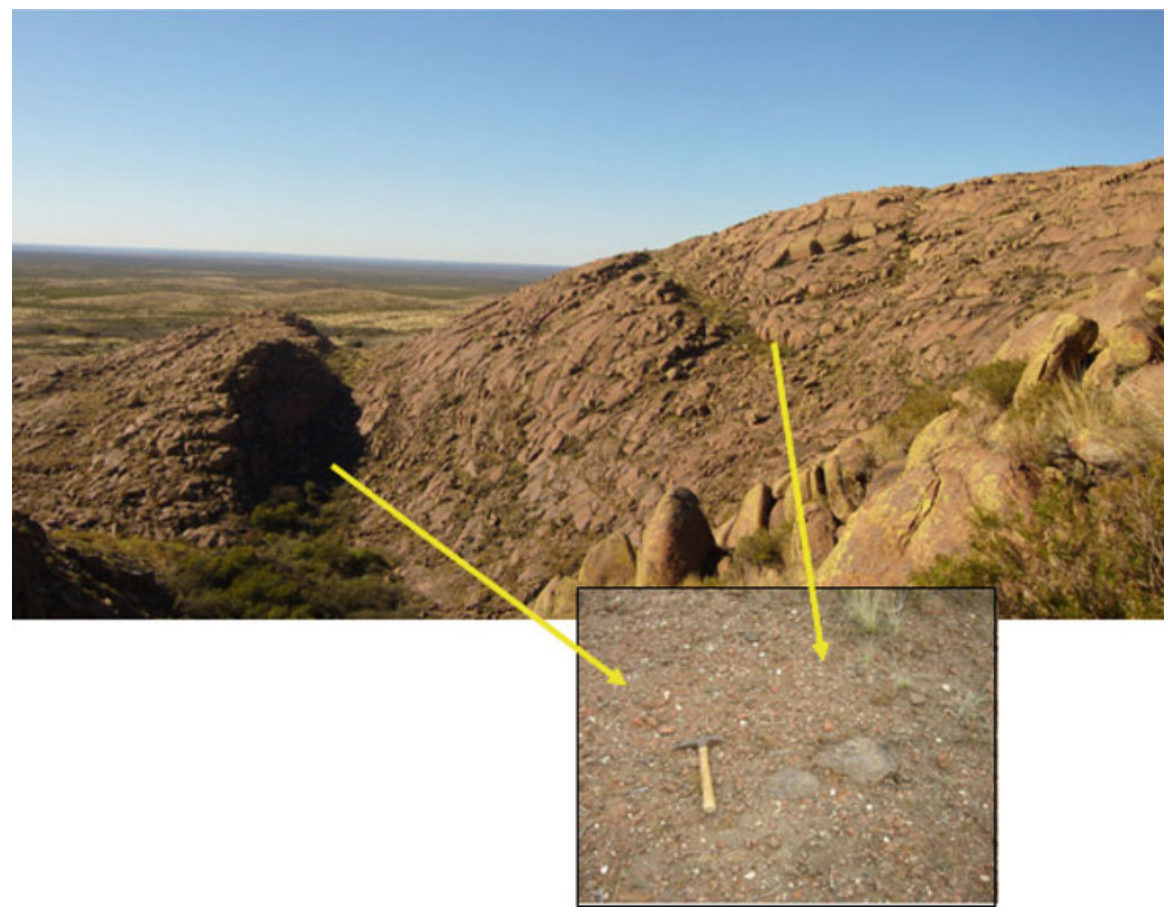

Fig. 17 Depressions bounding flow units, a product of regolith mobilization
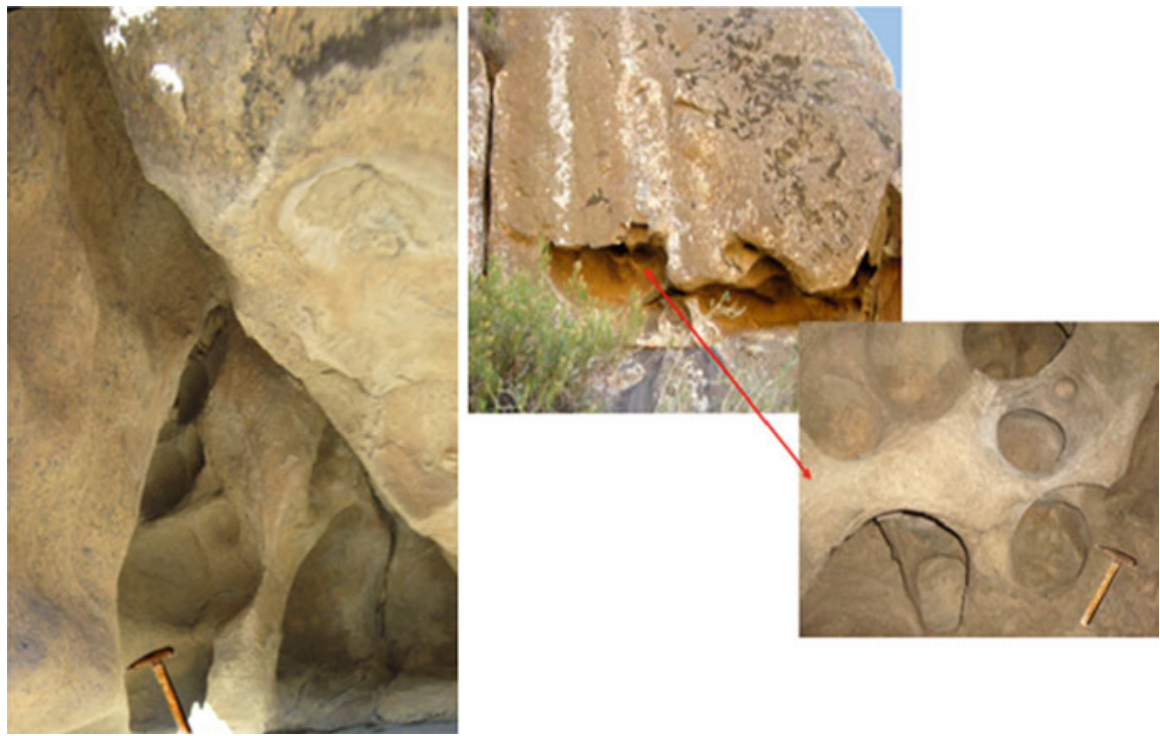

Fig. 18 Alveoli developed in the inner part of tafoni; some of them are separated by thin rock walls 

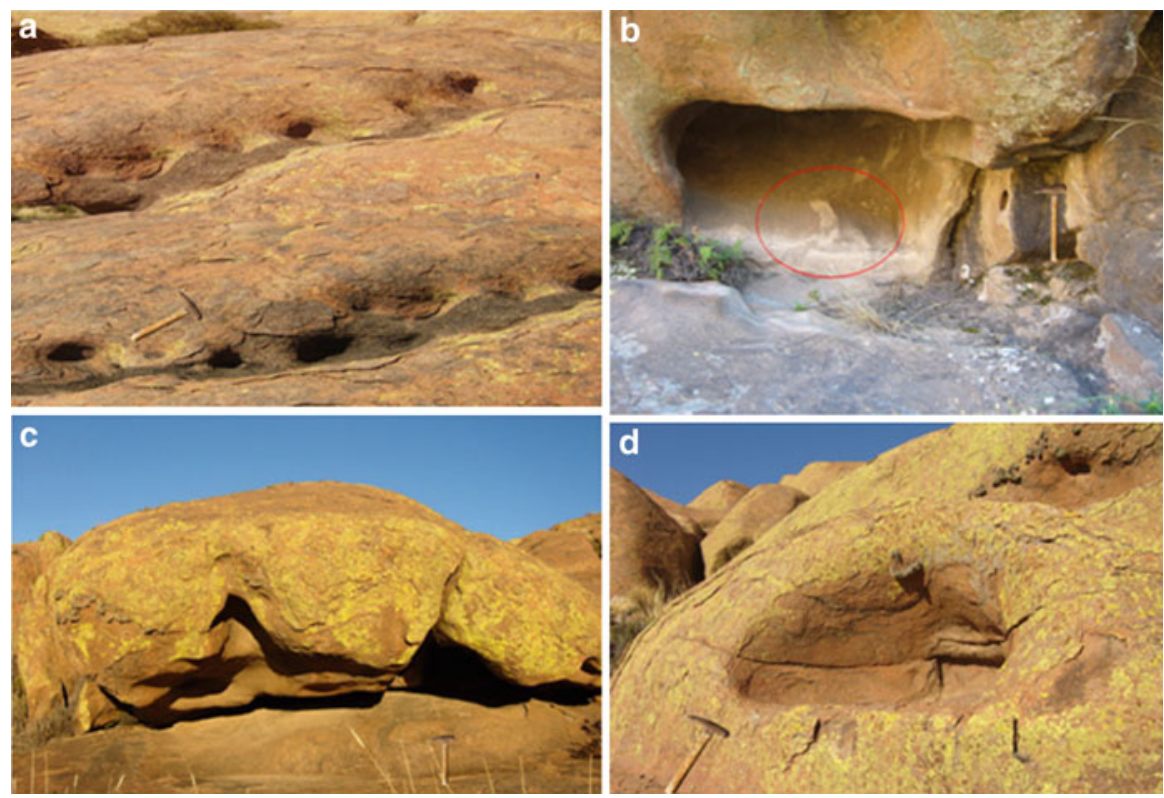

Fig. 19 (a) Tafoni appear as arranged in certain orientations, according to weakness surfaces within the ignimbrite mantles, following the boundaries in between flow units. (b) In the inner part, saline chemical precipitation is observed, in this case depicted by a red circle. (c) The inner part of the cavity is covered by alveoli, mamelonar shapes, and depressions of the scallop type. (d) Tafoni developed from fracture plane convergence

Tafoni are also integrated by cavities, which are larger than the hollows and big enough to develop caves. They occur grouped in circular or elliptical patterns, some of them with their floor covered by debris. In some opportunities, they appear arranged in certain orientations, according to weakness surfaces within the ignimbrite mantles, following the boundaries in between flow units (Fig. 19a). At the inner part of some tafoni, saline precipitation is observed, in this case depicted by a red circle (Fig. 19b). In other cases, the inner part of the cavity is covered by alveoli, with mamelonar shape and depressions of the scallop type (Fig. 19c). Some tafoni are developed following the convergence of fracture planes (Fig. 19d).

Gnammas, also known as weathering pits or rock basins, are depressions developed on surfaces with little inclination. They occur isolated or in groups. Their more frequent diameters are in the decimeter scale, though some others have been also identified at the centimeter scale or even surpassing a $1 \mathrm{~m}$ diameter. Their shapes are either circular or elliptical. Some of these gnammas are coalescent and their limiting borders are diffused (Fig. 20a). Others have a differential location along lines of weakness following joints (Fig. 20b), although in some cases they do not follow any visible structural control. It is common to observe the presence of outflow channels in some of these gnammas (Fig. 20c). These landforms, known in 

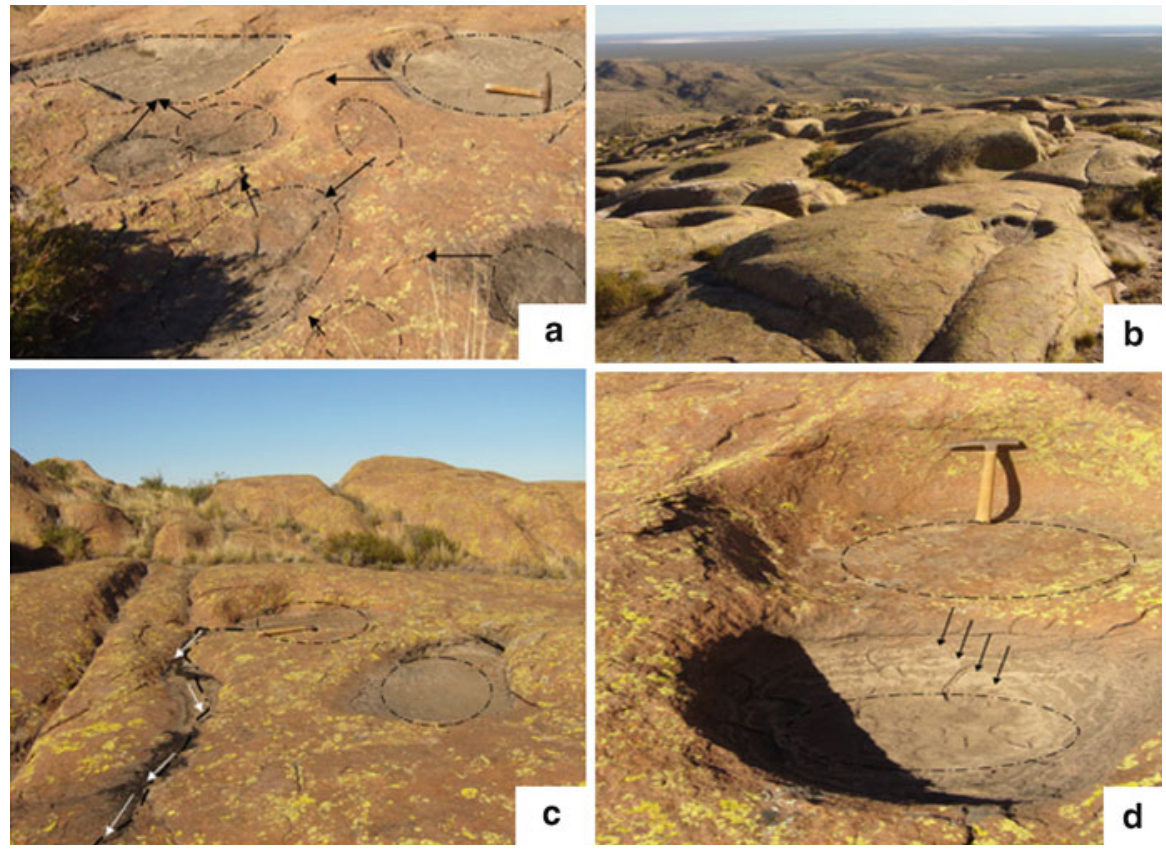

Fig. 20 (a) Convergent gnammas and their limiting borders are diffused. (b) Location along lines of weakness following joints. (c) Gnammas with extruding channel that discharges in the rills concentrating superficial runoff. (d) Cascading gnammas, which are produced by one gnamma located in an upper topographic level of the massif which becomes coalescent with gnammas at lower levels. The sediment yield follows the water discharge; note the sediments accumulated in the lower gnamma

the German language as Opferkessel and Blutrinnen, have different sizes even when developed in the same rocky surface, and this is interpreted as different stages of growth with evolution and continuous generation of new gnammas (Fig. 20d).

The landscape of the Sierra de Lihuel Calel allowed the recognition of all the types of gnammas: (a) pit gnammas, deeper than wider; (b) pan gnammas, rather shallow in relation to their diameter; in these features, overhanging slopes are frequent; (c) cylindrical basins; and (d) armchair gnammas, located in gentle slopes, with a triangular transversal section, which represent an intermediate step towards the tafoni morphology (Fig. 21).

Exfoliation includes flaking, spalling, and spheroidal weathering (Ollier 1965, 1967). Spalling is widely present, as granular disintegration and lichen colonization are. These surfaces show laminae of a few millimeter in thickness, which massively cover the entire outcrop (Fig. 22a, b). They are also observed in the inner portion of tafoni. Some boulders show not only sapling but spheroidal exfoliation (Figs. 22c and 23). 
a
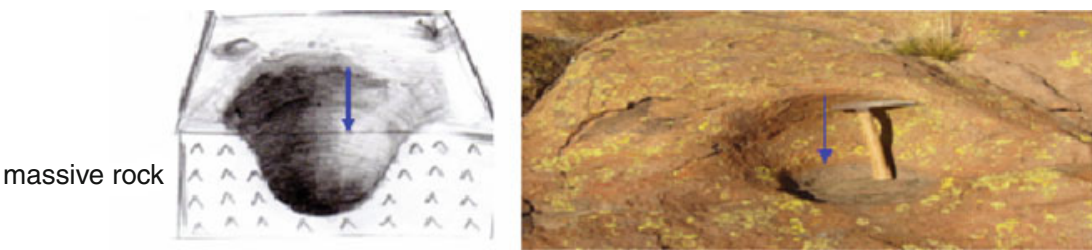

b

Rock with exfoliation (spalling, flaking) massive rock
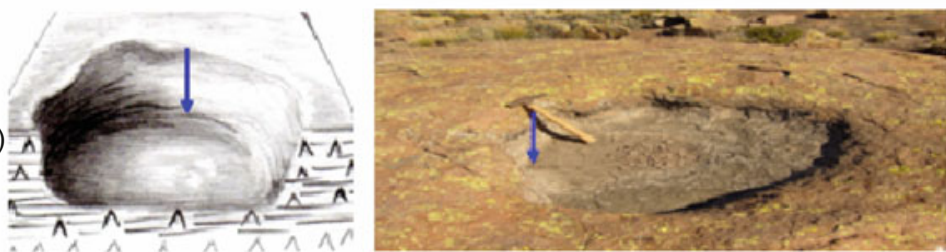

C

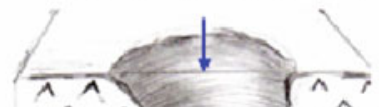

massive rocks
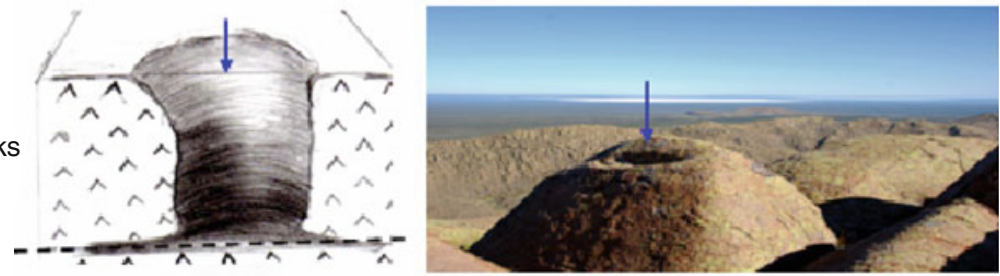

d sheet joint
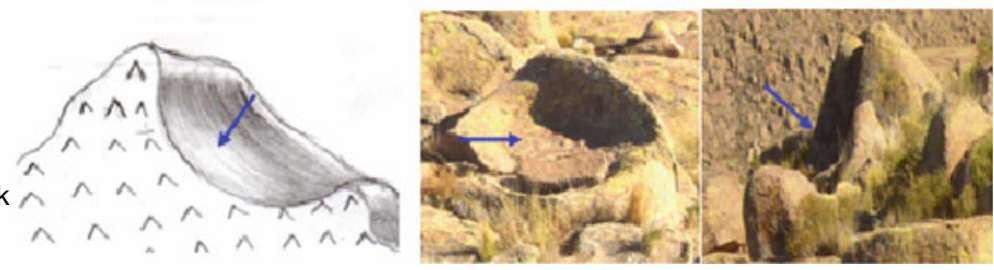

Fig. 21 The types of gnammas recognized in Lihuel Calel: (a) pit gnammas. (b) pan gnammas. (c) cylindrical basins, and (d) armchair gnammas

Bedrock drainage channels (also known as fluting, gutters, rille, and karren forms) are drainage channels that develop in the roofs and sides of domes, exhibiting incision of the dome due to these features. Some of them are controlled by structures or discontinuity surfaces. Their size is varied with an average depth of $10 \mathrm{~cm}$, width of 30-50 cm, and a longitude of several meters (Fig. 24a, b).

\section{Flared Slopes}

Along the margins of the rocky massifs and also along the sides of residual blocks and boulders, it has been observed that the development of slopes with steep inclination and concave cross section has been termed as "flared slopes." These features have also been called inverted slopes, excavated walls, and concave 


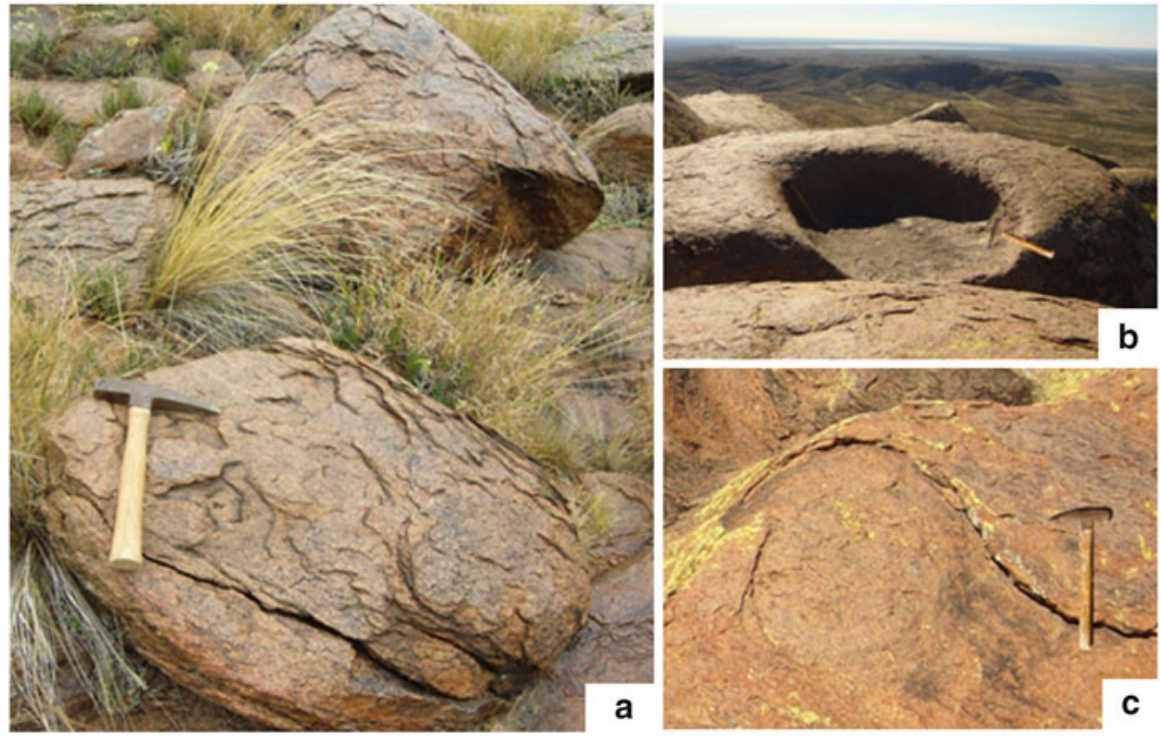

Fig. 22 (a) and (b) Flaking in rounded boulders, where numerous laminae occur as flakes. (c) Rock nucleus with flaking cover and incipient spheroidal exfoliation
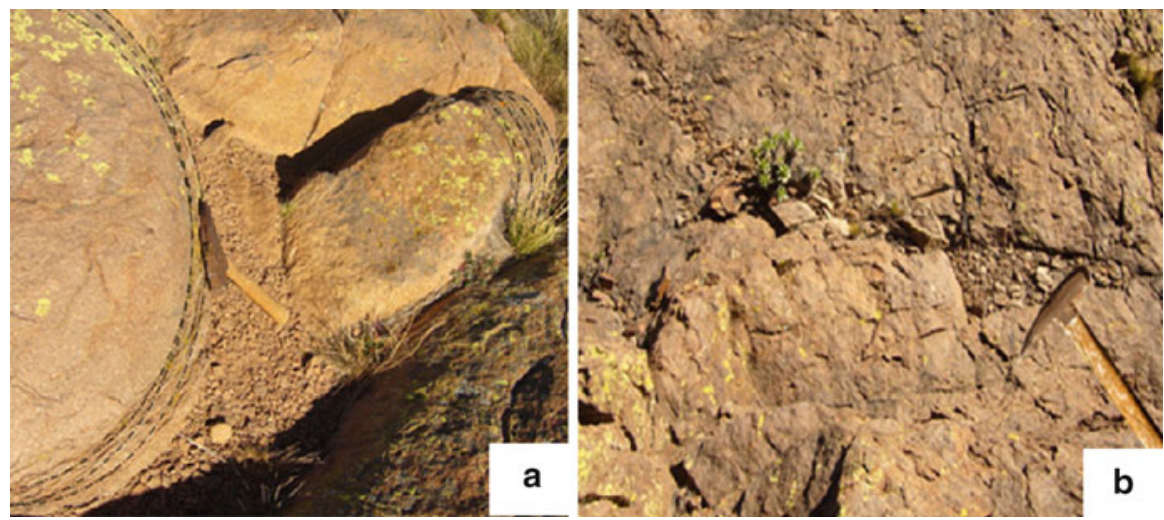

Fig. 23 (a) Rounded blocks with spheroidal exfoliation and granular disintegration. (b) Smallscale fracturing

slopes. At least three levels of flared slopes have been recognized in the study area (Fig. 25a). Those of larger dimensions reach the metric scale and correspond to the differentiated levels of the summit surface. Those flared slopes developed in residual boulders and blocks reach decimeter scale. Some of them show a lateral transition to cavities of the tafoni type. 

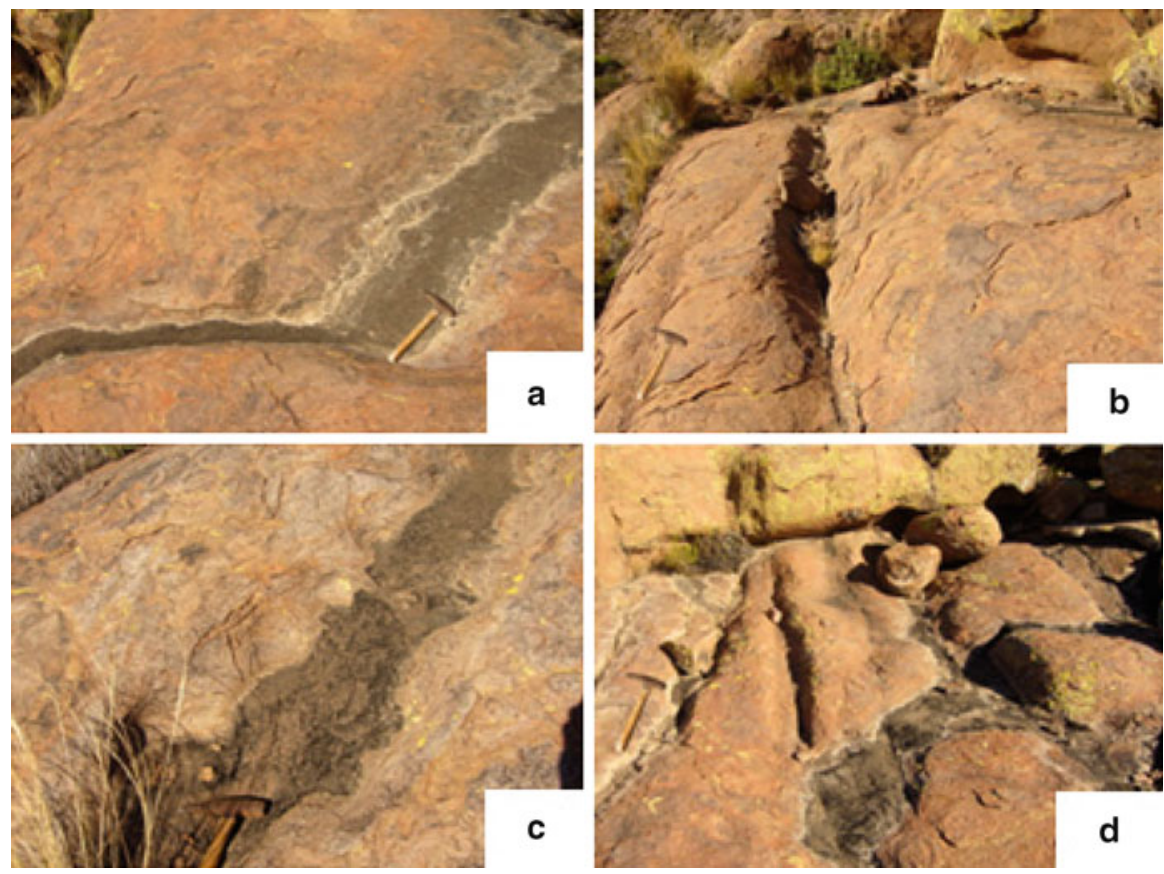

Fig. 24 Bedrock drainage channels; (a) and (c) channels in steep slopes; (b) and (d) parallel channels controlled by structure

\section{Discussion}

The study of these landforms has posed several questions:

(a) Are inselbergs formed by deep weathering and stripping or by fluvial erosion and slope retreat-forming pediments and pediplains?

(b) Are there common patterns between the landforms developed in ignimbrite rocks and those formed in granitic landscapes?

In the first case, concerning the formation of inselbergs, some authors attribute them to slope recession; another hypothesis includes two processes: deep weathering and planation (Twidale 1982); and a third one suggested mantle planation (Mabbutt 1961; Ollier 1978).

To a larger extent, these hypotheses not only explain the genesis of inselbergs, but they could be also applied to the formation of nubbins, castle koppies, tors, and other minor features.

Some tors are evidently the result of deep weathering, a product of a period of intense chemical weathering following joints and continued by a period in which the degraded material is mobilized. However, some tors lack these features indicating deep weathering, such as spheroidal weathering. These landforms suggest such 


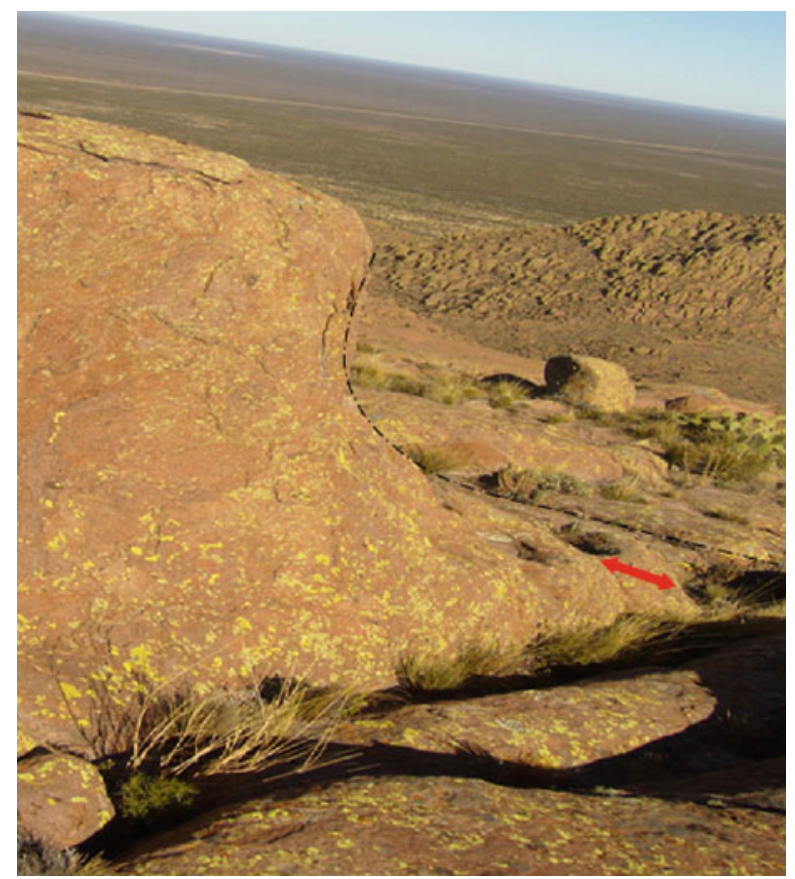

Fig. 25 Flared slope; note the development of the concave slope. At the base, a red arrow indicates the occurrence of several tafoni

genetic conditions in which weathering and denudation acted at the same time on rocks of different resistance, for instance in this case, welded ignimbrites and poorly welded ignimbrites.

With respect to flared slopes, the sub-superficial alterations of the rocky massif at the contact with the alteration mantle play a significant role in their formation (Twidale 1962). In those areas with scarce or null inclination, the corrosion plain is the product of a homogeneous alteration mantle (Twidale 1990). In the other extreme of the system, the exhumed reliefs are placed, where corrosion works in the margins of the rocky massif, progressively making even more vertical its walls. Chemical weathering is concentrated and reduced to zones favored by underground phreatic level. If the phreatic level is constant for a long period of time, undermining of the walls produced flare slope formation. The condition needed for its development is a stabilization of the alteration mantle, so as chemical weathering etched the morphology. In the second phase, the landform became exposed and degradation and stripping took place. Ollier and Bourman (2002) suggested that concave slopes may also be formed by subaerial weathering and that the retreat of these slopes may generate rectilinear footslopes. These rectilinear slopes have been related to flared slopes. The combination of concave and rectilinear slopes may produce convergent relief features that may be formed by different processes. 
Gnammas (rock basins) are genetically related to weathering and mechanical erosion, because these cavities may retain water and clastic, loose materials as products of the cavity growth. This material is removed by water currents and it erodes and enlarges the cavity.

(c) The common patterns developed in the Lihuel Calel ignimbrites are similar to those found in typical granitic landscapes.

In the granitic landscapes, weathering acts along joint systems that are bounding blocks. Such weathering is not homogeneous, since it is more intense in the margins and much less effective in the remaining parts of the blocks. For this reason, the blocks which were originally subangular and angular are gradually advancing in their degree of roundness. Likewise, the weathered rock is usually removed and denudated, finally exposing the rounded rock nuclei, such as corestones and other boulders.

In the Sierra de Lihuel Calel example, the development of unloading joints, parallel to the topographic surface (sheeting) and others of subcircular pattern, would be able to control the development of nubbins and tors.

Another intervening similitude parameter is the massive character (of textural nature) of the rock. In ignimbrites, the poikilitic overgrowth of the quartz and feldspar crystalloclasts provided the rock an even stronger cohesion and a "porphyritic" appearance, typical of coherent igneous rocks, as could be a sub-volcanic or plutonic intrusive body.

\section{Conclusions}

With respect to the genesis of the larger- and smaller-scale landforms recognized in the Sierra de Lihuel Calel, the joint action of several agents such as weathering (either sub-surficial or subaerial), slope retreat and, to a lesser proportion, fluvial action would be responsible of their formation.

The exposure of the weathering front, the exhumation of corestones included in a regolith mantle and showing spheroidal weathering suggests the participation of sub-superficial alteration with a later removal of the regolith.

Weathering intervenes in the disaggregation of the materials following the joint systems, as the depressions are deepened and slope retreat achieves a larger significance, acting these processes in a combined manner (mixed genesis), perhaps in response to small variations of the climatic factors, considering also that certain forms of subsurface weathering are superimposed on subaerial weathering forms, as in the case of spheroidal weathering in corestones with flaking exfoliation, which sometimes may mask other types.

This landscape of inselbergs, nubbins, castle koppies, tors, and other landforms is developed on ignimbrite rocks, with textural properties and joint systems similar to those occurring in granitic rocks. 
Acknowledgments This investigation was financed by the PIP Project 112-200801-00119 of CONICET. The authors are greatly indebted to Cliff Ollier for his permanent support and careful revision of the first draft of the manuscript and to Jorge Rabassa for his kind invitation to present this chapter.

\section{References}

Folgueras A, Zárate M (2009) La sedimentación neógena continental en el sector extrandino de Argentina central. Asociación Geológica Argentina, Revista 64(4):692-712

Linares E, Llambías EJ, Latorre C (1980) Geología de la provincia de La Pampa, República Argentina y geocronología de sus rocas metamórficas y eruptivas. Asociación Geológica Argentina, Revista 34(1):87-146

Llambías EJ (1973) Las ignimbritas de la sierra de Lihuel Calel, provincia de La Pampa. Actas 5 Congreso Geológico Argentino 4:55-67

Llambías EJ (1975) Geología de la provincia de La Pampa y su aspecto minero. Dirección de Minas de la provincia de la Pampa, Informe inédito, Santa Rosa, 38 p

Llambias EJ (2003) Geología de los cuerpos ígneos. Instituto Superior de Correlación Geológica y Asociación Geológica Argentina Serie de Correlación Geológica 15:1-182

Llambías EJ, Leveratto MA (1975) El plateau riolítico de la provincia de La Pampa, República Argentina. Actas II Congreso Iberoamericano de Geología Económica 1:99-114

Mabbutt JA (1961) Basal surface or weathering front. Proc Geol Assoc Lond 72:357-358

McArthur AN, Cas RAF, Orton GJ (1998) Distribution and significance of crystalline, perlitic and vesicular textures in the Ordovician Garth Tuff (Wales). Bull Volcanol 60:260-285

McPhie J, Doyle M, Allen R (1993) Volcanic textures: a guide to the interpretation of textures in volcanic rocks. CODES Key Centre, Hobart, $197 \mathrm{pp}$

Ollier CD (1965) Some features of granite weathering in Australia. Zeitschrift für Geomorphologie 9:285-304

Ollier CD (1967) Spheroidal weathering, exfoliation and constant volume alteration. Zeitschrift für Geomorphologie 11(1):103-108

Ollier CD (1978) Inselbergs of the Namib Desert, processes and history. Zeitschrift fir Geomorphologie, Supplement 31:161-176

Ollier CD (1988) Volcanoes. Blackwell, Oxford, $228 \mathrm{p}$

Ollier CD (1991) Ancient landforms. Belhaven, London, p 233

Ollier CD, Bourman RP (2002) Flared slopes, foot-slopes, and the retreat of overhanging slopes: examples of convergent landform development. Phys Geogr 23:321-334

Ramos VA (1999) Las Provincias Geológicas del Territorio Argentino. Geología Argentina, Instituto de Geología y Recursos Minerales, Anales 29(3):41-96, ISSN:0328-2325

Rapela CW, Pankhurst RJ, Llambías EJ, Labudía C, Artabe A (1996) "Gondwana" magmatism of Patagonia: inner Cordilleran calc-alkaline batholiths and bimodal volcanic provinces. In: Third international symposium on Andean geodynamics, Saint-Malo, France, pp 791-794

Sato AM, Tickyj H, Llambías EJ, Sato K (2000) The Las Matras tonalitic-trondhjemitic pluton, central Argentina: Grenvillian-age constraints, geochemical characteristics, and regional implications. J S Am Earth Sci 13:587-610

Sruoga P, Llambías EJ (1992) Permo-Triassic leucorhyolitic ignimbrites at Sierra de Lihuel Calel, La Pampa province, Argentina. J S Am Earth Sci 5(2):141-152

Tickyj H, Basei MAS, Sato AM, Llambías EJ (1999) U-Pb and K-Ar ages of Pichi Mahuida Group, crystalline basement of south-eastern La Pampa province, Argentina. In: Actas II South American symposium on isotope geology, Carlos Paz, Argentina, pp 139-144

Twidale CR (1962) Steepened margins of the inselberg from north-western Eyre Peninsula, South Australia. Zeitschrift fur Geomorphologie 6:51-69

Twidale CR (1982) Granite landforms. Elsevier, Amsterdam, 372 pp 
Twidale CR (1983) Pediments, peneplains and ultiplains. Revue de Geomorphologie Dynamique 32:1-35

Twidale CR (1990) The origin and implications of some erosional landforms. J Geol 98:343-364

Vidal Romaní JR, Twidale CR (1998) Formas y paisajes graníticos. Universidade da Coruña, A Coruña, $411 \mathrm{pp}$

Widdowson M (ed) (1997) Palaeosurfaces: recognition, reconstruction and palaeoenvironmental interpretation, Special publication, 120. Geological Society of London, London

Wilson CJN (1993) Stratigraphy, chronology, styles, and dynamics of late Quaternary eruptions from Taupo volcano, New Zealand. Philos Trans R Soc Lond A 343:205-306

Zárate MA, Folguera A (2014) Planation surfaces of Central Western Argentina. In: Rabassa J, Ollier C (eds) Gondwana landscapes in southern South America. Springer, Dordrecht, pp 365-392 